\title{
PRAWO WYBORCZE DO SEJMU USTAWODAWCZEGO
}

\author{
ELECTORAL LAW TO THE LEGISLATIVE SEJM
}

The legislative works conducted by Jędrzej Moraczewski's government were a key element of the process begun in the fall of 1918, aimed at establishing a democratic electoral law to the constituent assembly, including both women and men. Between 18 and 27 November 1918 its members prepared two drafts regulating the matter in detail. Both decrees were signed by Chief of State Józef Piłsudski on 28 November 1918. The elections effected on the basis of provisions contained therein were held on 26 January 1919. As a result, political representation of Poland reborn after decades of partitions was established. However, opening of the debates of the Legislative Sejm did not terminate activities related to electing Deputies, as the legal status of the lands, which were to be a part of the re-established state according to J. Piłsudski and subsequent cabinets, had still not been determined. Actions in this sphere were continued by Polish authorities on the basis of various normative solutions until March 1922. Indubitably, those efforts - taking into consideration both their systemic and social significance - had gone down in history of the Second Republic of Poland.

Słowa kluczowe: wybory, prawo wyborcze, projekt, ordynacja wyborcza, dekret, ustawa, rząd Jędrzeja Moraczewskiego, Sejm Ustawodawczy, Naczelnik Państwa Józef Piłsudski

Key words: elections, electoral law, draft, electoral ordinance, decree, act, Jędrzej Moraczewski’s government, Legislative Sejm, Chief of State Józef Piłsudski

* Dr Kamil Kacperski, Polskie Towarzystwo Stosunków Międzynarodowych, k.kacperski@onet.eu

I. ZAGADNIENIE PRAWA WYBORCZEGO DO KONSTYTUANTY W ŚWIETLE DECYZJI USTROJOTWÓRCZYCH PODJĘTYCH PRZEZ RZĄDY IGNACEGO DASZYŃSKIEGO I JĘDRZEJA MORACZEWSKIEGO ORAZ NACZELNIKA PAŃSTWA JÓZEFA PILSUDSKIEGO

$U_{d}^{h}$ konstytuowanie się w nocy z 6 na 7 listopada 1918 r. Tymczasowego Rządu Ludowego Republiki Polskiej otworzyło nowy rozdział w ramach zainicjowanego pięć miesięcy wcześniej procesu formowania prawa wyborczego do jednoizbowego organu przedstawicielskiego ${ }^{1}$. Gabinet pod przywództwem Ignacego Daszyńskiego z Polskiej Partii Socjalno-Demokratycznej Galicji i Śląska Cieszyńskiego [dalej: PPSD] w proklamowanym tej samej nocy manifeście Do Ludu Polskiego zapowiedział, że: „Sejm Ustawodawczy zwołany będzie przez nas jeszcze w roku bieżącym na podstawie powszechnego, bez różnicy płci, równego, bezpo-

1 Mowa tu o czynnościach jurydycznych, jakie podjęła Komisja Administracyjna Biura Pracy Społecznej jeszcze w okresie okupacji terenów Królestwa Polskiego przez Niemcy i Austro-Węgry. Vide K. Kacperski, Koncepcje systemu wyborczego do Sejmu na ziemiach Królestwa Polskiego w latach 1917-1918, Warszawa 2018, s. 233 i n. 
średniego, tajnego i proporcjonalnego głosowania. Ordynacja wyborcza będzie ogłoszona w ciagu kilku najbliższych dni. Czynne i bierne prawo wyborcze będzie przysługiwało każdemu obywatelowi i obywatelce mającym 21 lat skończonych"”. W ten sposób członkowie utworzonego w Lublinie rządu, mimo że reprezentowali głównie stronnictwa lewicy niepodległościowej z Królestwa Polskiego i Galicji, znacząco wpłynęli na zakres prowadzonej wtedy - nie tylko na forum publicznym, ale i w wymiarze urzędowym - debaty ustrojowej, której istota dotyczyła mechanizmów kreacji pierwszego parlamentu w dziejach II RP³. W dniu 11 listopada $1918 \mathrm{r}$. Rząd Ludowy podporządkował się zwolnionemu z niemieckiej niewoli Józefowi Piłsudskiemu4 $u^{4}$ Trzy dni później wydał on dekret formalnie mianujący I. Daszyńskiego premierem $^{5}$. W treści tego dokumentu podkreślono, że gabinet Daszyńskiego — z racji przejściowego charakteru - ma za zadanie jedynie administrowanie wolnymi ziemiami polskimi. Deklaracja ta stanowiła odwzorowanie poglądów J. Piłsudskiego, który w owym czasie twierdził, że najważniejsze decyzje w odradzającym się państwie może podejmować wyłącznie Sejm Ustawodawczy [dalej: SU] ${ }^{6}$.

W dniu 17 listopada 1918 r. I. Daszyński został zastapiony na stanowisku premiera przez Jędrzeja Moraczewskiego (PPSD) 7 . Działalność nowego gabinetu, w skład którego wchodziło także kilku ministrów zasiadających uprzednio w Rządzie Ludowym, zgodnie z zamysłem wyrażonym przez J. Piłsudskiego, miała przede wszystkim koncentrować się na wypracowaniu prawa wyborczego do konstytuan-

2 K.W. Kumaniecki, Odbudowa państwowości polskiej. Najważniejsze dokumenty: 1912-styczeń 1924, Kraków 1924, s. 130-132. Temat ten poruszono także w „Jedności Robotniczej”: „Jesteśmy świadkami faktu, że zarówno w różnych zrzeszeniach społecznych, jak i organizacjach wypracowujących projekty ustaw wyborczych do ciał przedstawicielskich, przyjmuje się zasada przyznania kobietom biernego i czynnego prawa wyborczego. Idzie teraz o to, by kobiety same zrozumiały, jak żywotnym jest ich interes w uzyskiwaniu wpływu na tok spraw politycznych, by kobieta zdolną była do zerwania z kompromisem i jako człowiek pracujący i obywatelka stanęła obok męskiego swego towarzysza do twórczej pracy dla jutra". Vide Kobiety a Sejm, ,Jedność Robotnicza” z 17 XI 1918 r., nr 46, s. 6.

3 S. Thugutt (PSL ,Wyzwolenie”), pełniący w tym rządzie funkcję ministra spraw wewnętrznych, odnosząc się wówczas do problematyki wyłonienia parlamentu napisał: „Musi być powołany Sejm. Tylko z tego Sejmu wytryśnie żywy zdrój siły, tylko ten Sejm będzie Polską, będzie mógł w jej imieniu ostatnie słowo powiedzieć”. Vide Czego żądać od rządu, „Wyzwolenie” z 10 XI 1918 r., nr 45, s. 397.

4 A. Ajnenkiel, Spór o model parlamentaryzmu polskiego do roku 1926, Warszawa 1972, s. 168. Natomiast trzy dni później rozwiązała się Rada Regencyjna. J. Pajewski, Odbudowa państwa polskiego 1914-1918, Warszawa 1978, s. 298.

${ }^{5}$ Dekret naczelnego dowódcy Józefa Piłsudskiego z dnia 14 listopada 1918 r., Dziennik Praw Państwa Polskiego [dalej: Dz.P.P.P.] z 1918 r. nr 17, poz. 40. Vide też B. Hełczyński, Józef Piłsudski jako Naczelnik Państwa (listopad 1918-grudzień 1922), „Niepodległość”, t. 9, Londyn-Nowy York 1974, s. 290.

${ }^{6}$ Należy zaznaczyć, że Rząd Ludowy podjął działania, których istota ogniskowała się wokół przygotowania przepisów prawa wyborczego do konstytuanty. I. Daszyński, omawiając tę kwestię, stwierdził: „W późną noc siedzieliśmy z panem Thuguttem nad przyszłą sejmową ordynacją wyborczą, ale zdaje mi się, żeśmy jej całkowicie nie skończyli, bo już czasu zabrakło". Rok 1918 we wspomnieniach mężów stanu, polityków i wojskowych, wybrał i opracował J. Borkowski, Warszawa 1987, s. 89.

7 Monitor Polski [dalej: M.P.] z 1918 r. nr 206. A. Garlicki, analizując te wydarzenia, zauważył: „Z punktu widzenia celów Piłsudskiego rząd Moraczewskiego był ową przykrą koniecznością, był ustępstwem na rzecz wymogów chwili i rezultatem krótkowzroczności prawicy. Dlatego traktował go jako swoiste prowizorium, poszukując jednocześnie możliwości rozszerzenia jego oparcia na prawo". A. Garlicki, Józef Pitsudski 1867-1935, Warszawa 1988, s. 205. 
ty ${ }^{8}$. W tej sytuacji rząd problematyką wyborczą zajął się już na pierwszym posiedzeniu (pkt 4 obrad). Odbyło się ono 18 listopada 1918 r. ${ }^{9}$ Premier Moraczewski zapowiedział wówczas uwzględnienie w porządku „najbliższych posiedzeń Rady Ministrów, jako bardzo pilnej, sprawy ordynacji wyborczej do Sejmu Ustawodawczego" ${ }^{10}$. Przytoczona enuncjacja znalazła swoje odzwierciedlenie w postaci projektu normującego tę kwestię ${ }^{11}$ napisanego w niespełna dwie doby przez ministra spraw wewnętrznych Stanisława Thugutta z Polskiego Stronnictwa Ludowego [dalej: PSL] „Wyzwolenie”, Naczelnika Wydziału Sejmowego w Ministerstwie Spraw Wewnętrznych [dalej: MSW] Mieczysława Niedziałkowskiego z Polskiej Partii Socjalistycznej [dalej: PPS] i dyrektora Głównego Urzędu Statystycznego prof. Józefa Buzka. Jego podstawą były regulacje zawarte w przedłożeniach sporządzonych w latach 1917-1918 przez Komisję Sejmowo-Konstytucyjną Tymczasowej Rady Stanu [dalej: KS-K TRS], rządy pod przywództwem Jana Kantego Steczkowskiego i Józefa Świeżyńskiego, Komisję Administracyjną Biura Pracy Społecznej [dalej: KA BPS] oraz prof. Józefa Siemieńskiego ${ }^{12}$.

Przywołany wniosek stał się przedmiotem obrad gabinetu w okresie od 19 do 27 listopada 1918 r. $^{13}$ Prowadzone w tych dniach postępowanie legislacyjne można podzielić na dwa etapy ${ }^{14}$. Pierwsza odsłona analizowanego procesu ogniskowała się zarówno wokół uregulowania naczelnych zasad prawa wyborczego, jak i zredagowania poszczególnych przepisów zamieszczonych w przedłożeniu. Mechanizmy normatywne, które zostały zawarte w projekcie, nie wzbudziły wśród ministrów większych kontrowersji. W dniu 19 listopada (3. posiedzenie, pkt 5 obrad) rząd przegłosował zatem artykuły od 1 do 22, 20 listopada (4. posiedzenie, pkt 2 obrad)

${ }^{8}$ Po latach ukazała się relacja J. Piłsudskiego ze spotkania, w trakcie którego przekazał on swoje oczekiwania J. Moraczewskiemu: „Kazałem mu stanąć na baczność, potem mu powiedziałem: Panie kapitanie, ma Pan zostać Prezesem Ministrów, ale pod dwoma warunkami: 1) by Pan nie wkraczał swymi zarządzeniami w jakiekolwiek stosunki społeczne, 2) wypracuje Pan w ciagu jednego tygodnia ustawę wyborczą i to tak, jak gdyby miał Pan budować okopy”. B. Hełczyński, Józef Piłsudski..., s. 291.

9 Archiwum Akt Nowych [dalej: AAN], Prezydium Rady Ministrów [dalej: PRM], Protokoły z posiedzeń Rady Ministrów 18 XI-31 XII 1918 r., t. 4, k. 317, sygn. 20048.

10 Zagadnienie to zostało wprowadzone także do porządku dziennego, wyznaczonego na 19 listopada 1918 r., 2. posiedzenia rządu (pkt 2 obrad). Ibidem, k. 317 i 328. Confer Kronika polityczna, „Robotnik” z 19 XI 1918 r., nr 303, s. 2.

11 AAN, PRM, t. 4, k. 335-348.

12 Vide K. Kacperski, Koncepcje systemu..., s. 21 i n.

${ }_{13}$ Ministrowie w proklamowanym 20 listopada 1918 r. manifeście Do Narodu Polskiego napisali: „Sejm Ustawodawczy, oparty na powszechnym, równym, bezpośrednim, tajnym i proporcjonalnym głosowaniu wszystkich obywateli i obywatelek, mających 21 lat skończonych, zdecydowani jesteśmy zwołać w początku roku przyszłego, ustalając dzień wyborów na ostatnią niedzielę stycznia. Przygotowania do tego aktu rozpoczynamy niezwłocznie, zaś ordynacja wyborcza zostanie przez nas ogłoszona w dniach najbliższych”. M.P. z 1918 r. nr 208.

${ }^{14}$ Ciekawą uwagę w tym względzie poczynił publicysta A. Trzaska-Chrząszczewski: „Gabinet Moraczewskiego zbierał się na posiedzenia [...] późnym wieczorem i odbywał swoje narady przeważnie nocą. Niekiedy przed posiedzeniem przyjeżdżał Piłsudski i odbywał krótką naradę z Moraczewskim. W posiedzeniach Rady Ministrów udziału nie brał. Było jednak widoczne, że udzielał swoich dyrektyw premierowi, które miały charakter hamujący ferwor reformatorski gabinetu”. A. Trzaska-Chrząszczewski, Wspomnienia i rozważania z lat 1887-1957, t. 1, 1887-1922, k. 145-146, sygn. 14098/II. 
przyjął artykuły od 23 do 59, zaś 21 listopada (5. posiedzenie, pkt 11 obrad) zatwierdził artykuły od 60 do 107 ordynacji ${ }^{15}$. Ostateczny kształt przepisy tego aktu prawnego uzyskały 26 listopada (9. posiedzenie, pkt 6 obrad) ${ }^{16}$. Druga faza omawianych czynności jurydycznych dotyczyła natomiast wytyczenia granic okręgów wybor$\mathrm{czych}^{17}$. Zagadnienie to było rozpatrywane przez gabinet podczas czterech spotkań: 23 listopada (7. posiedzenie, pkt 2 obrad), 25 listopada (8. posiedzenie, pkt 3 obrad), 26 listopada (9. posiedzenie, pkt 6 i 8 obrad) i 27 listopada (10. posiedzenie, pkt 13 obrad) ${ }^{18}$. Minister Thugutt $\mathrm{w}$ trakcie zainicjowanej 23 listopada dyskusji na ten temat zaproponował, aby tereny Królestwa Polskiego zostały podzielone albo na okręgi trzymandatowe, albo na okręgi liczące od 5 do 8 mandatów. Rozwiązania te miały znaleźć zastosowanie również w Galicji (bez wschodniej jej części) i na Śląsku Cieszyńskim, z tym że w przypadku drugiego wariantu dopuścił on możliwość utworzenia nie tylko okręgów wielomandatowych, ale i jednomandatowych ${ }^{19}$. Rząd nie poparł żadnej z przedstawionych wtedy koncepcji. Większość jego członków uznała bowiem, że wybory powinny odbyć się na wszystkich ziemiach polskich, jednak ich rozpisanie miało nastapić wyłącznie ,tam, gdzie urzędują władze polskie”"20. Co więcej, gabinet — obawiając się deformacji wyniku głosowania — odrzucił zasadność wykorzystania, oprócz proporcjonalnego systemu wyborczego, także formuły większościowej. W konsekwencji podjętych wówczas decyzji urzędnicy zatrudnieni w MSW, których działalność koordynował J. Buzek, ukształtowali nowe rozstrzygnięcia w tej materii ${ }^{21}$. Poprawiona mapa okręgów wyborczych została zaprezentowana przez ministra Thugutta na plenum Rady Ministrów 25 listopada $^{22}$. Tego samego dnia nastapiło też jej zatwierdzenie ${ }^{23}$. W ostatniej kolejności gabinet w dniach 25, 26 i 27 listopada rozpatrzył kwestię zorganizowania wyborów na terenach dawnego zaboru pruskiego ${ }^{24}$. W myśl rozwiązań opracowanych w MSW planowano utworzyć tam 11 okręgów. Warto zaznaczyć, że legislatorzy objęli spisem okręgów nie tylko terytoria znajdujące się we władaniu Prusaków, na mocy uchwał Kongresu Wiedeńskiego z 1815 r., ale również Górny Śląsk i Mazury. Pomysł ten, którego referentem był M. Niedziałkowski, rząd zaaprobował 27 listopada ${ }^{25}$. Ostatecznie dobę później Naczelnik Państwa J. Piłsudski podpisał dwa - przedstawio-

${ }^{15} \mathrm{~W}$ trakcie tych czynności wykreślił on z procedowanego projektu sześć artykułów. AAN, PRM, t. 4, k. 326,349 i 361 .

${ }^{16}$ Legislatorzy dokonali wówczas punktowych korekt w ramach 11 przepisów tego przedłożenia. Ibidem, k. 410.

${ }^{17}$ Pierwotnie wniosek wypracowany w MSW stanowił, że wybory odbędą się jedynie na ziemiach Królestwa Polskiego. Tereny te miały zostać podzielone na 30 okręgów, w których można było uzyskać łącznie 185 mandatów. Ibidem, k. 344.

18 Ibidem, k. 379, 394, 410 i 423.

19 Ibidem, k. 362 i 379.

${ }^{20}$ Ibidem, k. 379.

${ }^{21}$ Ibidem, k. 362.

22 Ibidem, k. 394 i 397-399.

${ }^{23}$ Ibidem, k. 394.

${ }^{24}$ Ibidem, k. 394, 410 i 423.

25 Ibidem, k. 423 i 429. 
ne przez gabinet - dekrety systematyzujące problematykę wyborów do Sejmu Ustawodawczego ${ }^{26}$.

Prawo wyborcze do konstytuanty zostało przygotowane przez rząd Moraczewskiego w następstwie presji, jaką w tej sprawie wywierał J. Piłsudski, w trakcie niespełna dwóch tygodni. Osiągnięcie tego celu w tak krótkim czasie było możliwe dzięki wykorzystaniu przez Radę Ministrów przedłożeń będących rezultatem wysiłków instytucjonalnych przedsięwziętych przez KS-K, KA, rządy Steczkowskiego i Świeżyńskiego oraz J. Siemieńskiego ${ }^{27}$. Wbrew pozorom nie oznaczało to jednak, że sporządzone przez nią akty prawne stanowiły kopię wypracowanych wcześniej wniosków. Owszem, gabinet Moraczewskiego w ramach upublicznionych wtedy dekretów zamieścił dużą liczbę uformowanych w latach 1917-1918 mechanizmów kreacji parlamentu. Jednocześnie zawarł w nich, co należy podkreślić, wiele autorskich rozwiązań jurydycznych, które w zasadniczy sposób wpłynęły na proces kształtowania fundamentów demokratycznego, gwarantującego jednakowy status kobiet i mężczyzn, prawa wyborczego do organów przedstawicielskich na ziemiach polskich w XX w.

\section{PRAWO WYBORCZE DO KONSTYTUANTY - ANALIZA DEKRETÓW Z 28 LISTOPADA 1918 R.}

Ordynacja wyborcza do Sejmu Ustawodawczego liczyła 101 artykułów ${ }^{28}$. W jej skład wchodziło też pięć dodatków, za pośrednictwem których legislatorzy usystematyzowali spis okręgów wyborczych, określili liczbę mandatów przypadających na

${ }^{26}$ M. Niedziałkowski na ten temat napisał: „Gorączkowo, w dzień i w noc, przygotowywano i przerabiano w Ministerstwie Spraw Wewnętrznych — w związku z żądaniami delegacji dzielnic, prowincji i grup ludności — te dwa dokumenty. I gdy ujrzały one wreszcie światło dzienne, zdawało się, że ciężar olbrzymi spadł z serc i z myśli ówczesnych kierowników młodziuteńkiego państwa". M. Śliwa, Myśl polityczna Mieczysława Niedzialkowskiego (1893-1940), Warszawa 1980, s. 60. S. Thugutt z kolei zanotował: „O szóstej trzeba już być w pałacu Namiestnikowskim, gdzie się codziennie odbywała Rada Ministrów, trwająca czasami do pierwszej w nocy. Potem jeździłem często sam lub z Moraczewskim do Belwederu i o bardzo późnej godzinie mogłem dopiero zabrać się w łóżku do przeglądania najważniejszych chociażby papierów". S. Thugutt, Autobiografia, przedmowa A. Więzikowa, T. Janczak, Warszawa 1984, s. 116. Vide też Dekret Naczelnika Państwa z dnia 22 listopada 1918 r. o najwyższej władzy reprezentacyjnej Republiki Polskiej, Dz.P.P.P. z 1918 r. nr 17, poz. 41.

${ }^{27}$ Działania te wzbudziły w „Gazecie Warszawskiej” liczne zastrzeżenia: „Wiemy, że rząd dotychczas zadowolił się przeczytaniem i przyjęciem ordynacji wyborczej, ongi przez Biuro Pracy Społecznej zaprojektowanej. To chyba nie wystarcza, bo powyższa ordynacja stosuje się tylko do Królestwa Kongresowego. Trzeba zatem pomyśleć o czymś szerszym odpowiadającym wymaganiom doby obecnej i potrzebom narodu”. Vide J. Bartoszewicz, Zasada wyborcza dla Sejmu Konstytucyjnego, „Gazeta Warszawska” z 29 XI 1918 r., nr 14, s. 1. W odpowiedzi na zarzuty w tej materii S. Thugutt powiedział: „Krytykują ustawę wyborczą? Myśmy przecież przyjęli tę, jaką nam zostawili nasi poprzednicy, wprowadzając kilka zaledwie zmian. Być może ustawa jest niedoskonała. Przyszły Sejm może ją poprawić, zmienić. Teraz nie było na to czasu. Lepszy Sejm na niedoskonałej nawet ustawie wyborczej oparty, niż dalsza zwłoka, niż ta pokątna walka wszystkich ze wszystkimi”. Vide Rozmowa z ministrem spraw wewnętrznych, „Kurier Polski” z 11 XII 1918 r., nr 309, s. 3.

${ }^{28}$ Dekret z dnia 28 listopada 1918 r. o ordynacji wyborczej do Sejmu Ustawodawczego, Dz.P.P.P. z 1918 r. nr 18, poz. 46. Należy podkreślić, że konstytuanta nie była ograniczona wymogiem kadencyjności. O wygaśnięciu jej pełnomocnictw nie decydował bowiem upływ czasu, a moment ukończenia prac nad konstytucją. W. Komarnicki, Polskie prawo polityczne (geneza i system), Warszawa 1922, s. 55. 
poszczególne okręgi wyborcze, ustalili wzory — listy wyborców, karty do głosowania i formularza protokołu głosowania oraz wyjaśnili mechanizmy przeliczania głosów na mandaty.

Na podstawie art. 1 czynnym prawem wyborczym dysponowali obywatele państwa, którzy do dnia ogłoszenia wyborów ukończyli 21 lat ${ }^{29}$. Przepis ten obejmował każdego obywatela państwa polskiego bez względu na jego płeć ${ }^{30}$. Dzięki temu kobiety po raz pierwszy w historii Polski formalnie uzyskały możliwość wzięcia udziału w wyborach do Sejmu ${ }^{31}$. W tym kontekście należy jednak zaznaczyć, że przytoczony artykuł - warunkujący obowiązywanie w praktyce zasady powszechności prawa wyborczego - został sformułowany niestarannie w wymiarze stylistycznym. Analizujący ówcześnie tę kwestię prof. J. Siemieński stwierdził nawet, że zamieszczone w nim postanowienia były zrozumiałe „głównie dla osób znających język rosyjski, jako że w zdaniu: «który do dnia ogłoszenia wyborów ukończył 21 lat», wyraz «do» użyty został w znaczeniu «przed» zgoła nie po polsku. [...] Widocznie redaktor ostateczny ustawy powziął płonną obawę, że tekst w dniu oznaczałby wyłącznie tych, co w sam dzień zarządzenia wyborów osiagnną wiek wyborczy, tak że wszyscy pozostali obywatele, liczący w dniu zarządzenia wyborów ukończonych 21 lat z najmniejszym choćby okładem - byliby pozbawieni praw wyborczych" ${ }^{\prime 32}$. Co więcej, regulacje zawarte w art. 1 stają się jeszcze mniej klarowne, gdy skonfrontuje się je z treścią następnego przepisu. Art. 2 stanowił bowiem, że wyborcy musieli być mieszkańcami obwodu głosowania, w którym głosuja, przynajmniej od przedednia zarządzenia wyborów. Tymczasem w art. 1 legislatorzy posłużyli się wyrażeniem „ogłoszenie wyborów”33. Rozbieżność ta, wynikająca z nieuwagi normodawców, mogła skutkować niespójnością terminów prekluzyjnych zapisanych w kalendarzu wyborczym ${ }^{34}$. Finalnie niebezpieczeństwo,

${ }^{29} \mathrm{~W}$ dniach 10, 20 i 27 listopada 1918 r. odbyły się w Warszawie manifestacje zorganizowane przez kobiety. W ich trakcie domagały się one przyznania praw wyborczych w wyborach do Sejmu. Vide Polityczny wiec kobiet polskich, „Nowa Gazeta” z 13 XI 1918 r., nr 47, s. 1; Wiec kobiet polskich, „Bluszcz” z 30 XI 1918 r., nr 48, s. 359.

${ }^{30}$ Czołowa polska sufrażystka I. Moszczeńska na ten temat napisała: „Niechaj kobiety idą do urny wyborczej z tą świadomością, że nowe przyjęły na siebie obowiązki, że są wezwane do służby politycznej, z której sumiennie wedle swego najlepszego rozumienia wywiązać się powinny, że prawo wyborcze posiadają nie po to, by siebie, swoje stronnictwo lub klasę społeczną broniły przed możliwą krzywdą, lecz by troskliwą i czujną rozciaggały opiekę nad dolą ojczyzny”. Vide I. Moszczeńska, Kobiety na arenie politycznej, „Głos” z 27 XI 1918 r., nr 383, s. 2.

31 Rozwiązania, o których mowa, zyskały poparcie na łamach ,Zorzy”: „,Dobrze się więc stało, że ustawa o wyborach do pierwszego Sejmu polskiego nadaje kobietom takie same prawa wyborcze, jak mężczyznom. Zasługują one na to. Jest to nowość. Jest to bardzo doniosła zmiana. Wszak dotychczas kobiety nie brały u nas udziału ani w wyborach do Dumy, ani nawet w samorządzie gminnym, i nie zawsze były dopuszczane do narad o sprawach ogólnych, politycznych i społecznych. Stąd też wiele kobiet mniej się interesowała tymi sprawami, zajmując się prawie wyłącznie sprawami domowymi i gospodarczymi. Dziś wszystko to musi się zmienić”. Vide Kobiety a wybory do Sejmu, ,Zorza” z 19 I 1919 r., nr 3, s. 35-36.

32 J. Siemieński, Rozbiór krytyczny ordynacji wyborczej do Sejmu Ustawodawczego, Warszawa 1919, s. 10.

33 Wydaje się, że wyrażenie to powinno zostać zastapione określeniem ,zarządzenie wyborów”.

${ }_{34}$ Co więcej, 19 grudnia 1918 r. prawodawcy zdecydowali o przedłużeniu — o 10 dni — terminów prekluzyjnych zawartych w art. 43, 47, 51 i 54 ordynacji. Dekret z dnia 19 grudnia 1918 r. o przedłużeniu niektórych terminów prekluzyjnych przy wyborach do Sejmu Ustawodawczego, Dz.P.P.P. z 1918 r. nr 20, poz. 63. 
o którym mowa, dostrzegli także autorzy dekretu. Stąd też opublikowana przez nich w grudniu 1918 r. Instrukcja do ordynacji wyborczej do Sejmu Ustawodawczego nakazywała słowa „ogłoszenie wyborów” rozpatrywać jedynie w kontekście ostatniego zdania art. $15^{35}$. Zgodnie z art. 3 każdy wyborca mógł głosować tylko w jednym obwodzie głosowania ${ }^{36}$. W art. 4 zakazano wojskowym w służbie czynnej udziału w głosowaniu, art. 5 wyłączał natomiast z tego aktu osoby sądownie pozbawione praw obywatelskich. W myśl wieńczącego rozdział I art. 6 prawo głosowania miało być wykonywane osobiście.

Na mocy art. 7 bierne prawo wyborcze uzyskali wszyscy obywatele państwa polskiego bez względu na płeć, dysponujący czynnym prawem wyborczym, niezależnie od miejsca zamieszkania, jak również wojskowi ${ }^{37}$. Artykuł ten, zamieszczony w rozdziale II, został sformułowany w sposób budzący wątpliwości natury jurydycznej. W świetle zawartych w nim rozwiązań, aby mieć prawo wybieralności trzeba było posiadać czynne prawo wyborcze, a jak wcześniej zaznaczono, jego uzyskanie legislatorzy uzależnili od cenzusu domicylu. Z tego też powodu można przyjać, że prawem tym nie mogły legitymować się osoby niemające stałego, przynajmniej od przedednia zarządzenia wyborów, miejsca zamieszkania. Co oczywiste, z biernego prawa wyborczego nie mogli korzystać także Polacy, którzy zamieszkiwali tereny znajdujące się poza granicami wymienionych w dekrecie okręgów wyborczych. Art. 8 zabraniał wybierać urzędników państwowych władz administracyjnych, skarbowych i sądowych w okręgu, na który rozciagała się ich działalność służbowa ${ }^{38}$. Obostrzenie to nie obejmowało urzędników i wojskowych władz centralnych. Art. 9 odnosił się do wojskowych i płatnych urzędników państwowych, którzy zostali wybrani do Sejmu ${ }^{39}$. Nakazywał on zwolnienie takich osób z czynności służbowych na czas trwania mandatu ${ }^{40}$.

35 Biblioteka Szkoły Głównej Handlowej [dalej: BSGH], Instrukcja do ordynacji wyborczej do Sejmu Ustawodawczego, sygn. 167071.

${ }^{36}$ Dekret z 11 stycznia 1919 r. stanowił, że obywatelom spełniającym wymogi zapisane w art. 1 ordynacji, powracającym do Polski po 5 grudnia 1918 r., również przysługiwały prawa wyborcze. Dekret z dnia 11 stycznia 1919 r. o nadaniu praw wyborczych obywatelom, którzy po 5 grudnia 1918 r. powrócili do kraju, Dz.P.P.P. z 1919 r. nr 5, poz. 97.

37 Przepis, na podstawie którego żołnierze otrzymali prawo wybieralności, stał się przedmiotem rozważań ze strony adwokata L. Nowodworskiego. Jego zdaniem, zamieszczone w nim rozwiązanie było ze wszech miar korzystne, ponieważ nie pozwalało przenieść agitacji politycznej do armii, umożliwiając jednocześnie wybór do Sejmu osób, których wiedza wojskowa mogła zostać spożytkowana w zakresie obronności państwa polskiego. L. Nowodworski, O ordynacji wyborczej do pierwszego Sejmu Polskiego: wyjaśnienie i wskazówki praktyczne, Warszawa 1918, s. 10.

38 Wprowadzenie obostrzeń w tej materii rekomendował też Z. Cybichowski. Wskazywał bowiem, że zapobiegały one ,wykorzystywaniu wpływów, zdobytych przez urzędowanie, na korzyść uzyskania mandatu parlamentarnego". Z. Cybichowski, Polskie prawo państwowe, t. I, Warszawa 1929, s. 130.

${ }^{39}$ Na mocy dekretu z 8 lutego 1919 r. prawodawcy usunęli z art. 9 ordynacji słowo ,wojskowych”. Jednocześnie dopisali do niego drugi ustęp: „Przynależni do wojska w razie wyboru na posła zwalniają się zupełnie z armii polskiej na czas trwania mandatu poselskiego". Dekret z dnia 8 lutego 1919 r. w sprawie zmiany art. 9 dekretu o ordynacji wyborczej do Sejmu Ustawodawczego, Dz.P.P.P. z 1919 r. nr 14, poz. 198.

${ }^{40}$ W ocenie A. Bogusławskiego (PSL ,Wyzwolenie”) postanowienia te pozwalały posłowi być ,,człowiekiem swobodnym, niezależnym, ażeby każde nadużycie mógł wykryć i w Sejmie przedstawić, bez względu na to, czy to zrobi niższy, czy wyższy od niego urzędnik państwowy”. A. Bogusławski, O ordynacji wyborczej (objaśnienie ogłoszonej ordynacji wyborczej), Warszawa 1918, s. 13. 
Na podstawie art. 10 poseł powołany do płatnej służby państwowej przestawał być członkiem Izby. Przytoczony przepis nie dotyczył — podobnie jak artykuł poprzedni - ministrów, podsekretarzy stanu i profesorów wyższych uczelni ${ }^{41}$.

W myśl art. 11, którego postanowienia rozpoczynały rozdział III, wykaz okręgów wyborczych został wyszczególniony w dodatku $\mathrm{nr} 1^{42}$. Dodatek ten dzielił terytorium państwa polskiego na 71 okręgów, w których można było uzyskać w sumie 527 mandatów ${ }^{43}$. Królestwo Polskie wraz z Ziemią Białostocką podzielono na 34 okręgi wyborcze. Ich wielkość wahała się w granicach od 4 (nr 2 Suwałki, nr 5 Lipno i nr 34 Bielsk) do 16 (nr 16 Warszawa) mandatów ${ }^{44}$. Najwięcej utworzono okręgów sześcioi siedmiomandatowych: odpowiednio 9 i 7. Były one usytuowane w województwach warszawskim, kieleckim, łódzkim, lubelskim i białostockim. Czterem okręgom przyznano po 9 mandatów. Należały one do województw białostockiego i kieleckiego. Po 10 mandatów liczyły 4 okręgi wchodzące w skład województw lubelskiego i łódzkiego. Wytyczono także trzy okręgi ośmiomandatowe. Dwa z nich położone były w województwie warszawskim, a jeden w kieleckim. Trzy okręgi czteromandatowe wyodrębniono z kolei w województwach białostockim i warszawskim. W województwach warszawskim i łódzkim usytuowano też 2 okręgi pięciomandatowe. Łącznie na tych terenach repartycji podlegało 241 mandatów.

Galicja została podzielona na 24 okręgi wyborcze, a wraz ze Śląskiem Cieszyńskim liczyła ich $26^{45}$. W sumie agregowały one 174 mandaty ${ }^{46}$. Największy okręg — nr 52 (Kołomyja, woj. stanisławowskie) — obejmował 10 mandatów, w czterech

${ }^{41}$ Zdaniem W. Zwolińskiego dopuszczenie do udziału w wyborach ministrów i podsekretarzy stanu było słuszne, gdyż: „Urzędnicy władz głównych nie mają bezpośredniej styczności z ludnością; wpływy ich w wielkim mieście nie mogą być stosunkowo tak wielkie, jak na przykład wpływy komisarza powiatowego w obrębie jego powiatu”. W. Zwoliński, Polski Sejm Konstytucyjny, czyli , konstytuanta”, Warszawa 1918, s. 11.

42 Analizując tę kwestię, Z. Ilski trafnie zauważył: „Ten podział na okręgi był nowością; nie zawierał go żaden z wcześniejszych projektów”. Z. Ilski, Formuła wyborcza u progu niepodległej Polski (do $1922 \mathrm{r}$.), Torun 2013, s. 447.

${ }^{43}$ Koncepcję tę popierał W. Jodko-Narkiewicz (PPS): „Im więcej okręgów wyborczych, tym bardziej skład parlamentu odpowiada rzeczywistemu politycznemu obliczu kraju, tym większe jest zatem u wszystkich poczucie, że nikomu nie dzieje się krzywda". W. Jodko-Narkiewicz, Jaka powinna być ordynacja wyborcza do przyszłego Sejmu polskiego?, Warszawa 1918, s. 28. Odmienną opinię na ten temat wyraził z kolei J. Siemieński: „Jeżeli stan rzeczy jest taki, że ludzie z odległych okolic nie znają się wzajemnie i nie znają w ogóle nikogo, nawet najwybitniejszych obywateli, niezamieszkałych pośród nich, a nie umieją też dochodzić z obcymi do porozumienia - wybory w wielkich okręgach nie są w stanie dać wyrazu rzeczywistej woli politycznej takiego społeczeństwa”. J. Siemieński, Rozbiór krytyczny..., s. 26-27.

${ }^{44} \mathrm{~W}$ okręgu $\mathrm{nr}$ 1, obejmującym powiaty: kalwaryjski, wołkowyski, mariampolski i władysławowski, rząd - wobec wątpliwości dotyczących statusu państwowego tych ziem — nie określił liczby mandatów, które miały zostać rozdzielone w wyborach.

${ }^{45}$ Należy zauważyć, że na mocy dekretu o wyborach do Sejmu Ustawodawczego okręgi nr 35 (Cieszyn) i nr 35A (Frydek), które były usytuowane na Śląsku Cieszyńskim, połączono w jeden, ośmiomandatowy okręg wyborczy. Dekret z dnia 28 listopada 1918 r. o wyborach do Sejmu Ustawodawczego, Dz.P.P.P. z 1918 r. nr 18, poz. 47.

${ }^{46}$ Pierwotnie w okręgu nr 39 (Nowy Targ) repartycji miało podlegać 7 mandatów. Faktycznie ich liczba powinna być o jeden mandat większa. Błąd ten został spowodowany niewłaściwym zsumowaniem ludności, która zamieszkiwała wchodzące w jego skład powiaty. W wyborach wybrano 8 posłów, a pomyłkę tę sprostowano w Dz.P.P.P. z 1919 r. nr 40, [brak poz.]. 
najmniejszych wybierano zaś po pięciu posłów — nr 37 (Oświęcim), nr 38 (Wadowice), nr 40 (Nowy Sącz) i nr 46 (Przemyśl). Okręgi te znajdowały się w województwach krakowskim i lwowskim. Najwięcej - 10 - ukształtowano okręgów sześciomandatowych. Były one położone w województwach lwowskim i tarnopolskim. Wytyczono również cztery okręgi dziewięciomandatowe. Usytuowano je w województwach krakowskim, lwowskim, stanisławowskim i tarnopolskim. Przewidziano także istnienie sześciu okręgów, po trzy, siedmio- i ośmiomandatowych. Umiejscowiono je w województwach lwowskim, stanisławowskim, tarnopolskim, krakowskim i na Śląsku Cieszyńskim. Ziemie byłego zaboru pruskiego podzielono natomiast na 11 okręgów wyborczych, w których do zdobycia było 112 mandatów ${ }^{47}$. Najmniejszy okręg liczył trzy mandaty — nr 70 (Nysa), największe dwa zaś po 13 mandatów — nr 63 (Poznań) i nr 65 (Opole). Najwięcej — cztery — uformowano okręgów dwunastomandatowych. Ponadto utworzono po jednym okręgu siedmio-, ośmio-, dziewięcio- i jedenastomandatowym.

Na mocy art. 12 jeden poseł przypadał na 50 tys. mieszkańców okręgu, przy czym ułamki tej liczby większe niż 25 tys. osób, także powodowały przyznanie następnego mandatu. Przyjęcie tego rozstrzygnięcia oznaczało, że do polskiego prawa wyborczego po raz pierwszy formalnie wprowadzono, stosowaną również obecnie, zasadę jednolitej normy przedstawicielstwa ${ }^{48}$. Dzięki temu legislatorzy potwierdzili też obowiązywanie $\mathrm{w}$ ramach przepisów ordynacji zasady równości prawa wyborczego w aspekcie materialnym. W myśl art. 13 główna komisja wyborcza dzieliła okręg wyborczy na obwody głosowania ${ }^{49}$.

W rozdziale IV prawodawcy zamieścili szczegółowe rozwiązania w zakresie wyboru członków Izby. W świetle art. 14 wybory te miały być zarządzone przez Naczelnika Państwa. Na podstawie art. 15 wydane przez niego zarządzenie zawierało dzień głosowania, na który należało wybrać niedzielę lub święto ${ }^{50}$. Głosowanie to powinno zostać przeprowadzone jednego dnia na terenie całego państwa. Było ono wyznaczane najpóźniej na 60. dzień po dniu zarządzenia wyborów. Zarządzenie wyborów musiało zostać ogłoszone w Dzienniku Praw Państwa Polskiego oraz w dziennikach politycznych. Zgodnie z treścią ostatniego zdania tego artykułu, dzień ogłoszenia wyborów w Dzienniku Praw uważano za dzień zarządzenia wyborów. W art. 18 ustanowiono, że w każdym okręgu miała ukonstytuować się główna komisja wyborcza, zaś w każdym obwodzie głosowania - miejscowa komisja wyborcza. Ich powstanie

47 Vide też J. Pietrzak, O reprezentację byłego zaboru pruskiego w Sejmie Ustawodawczym w 1919 r., „Dzieje Najnowsze”, Wrocław-Warszawa 1976, nr 4, s. 7-14.

${ }^{48}$ Confer J. Buczkowski, Podstawowe zasady prawa wyborczego III Rzeczypospolitej, Lublin 1998, s. 146.

49 Zgodnie z treścią Instrukcji liczba mieszkańców obwodu głosowania, poza Galicją i Śląskiem Cieszyńskim, nie mogła przekroczyć 3 tys., a w miastach z populacją powyżej 10 tys. - 2 tys. BSGH, Instrukcja..., sygn. 167071 .

50 Rozwiązanie to skrytykowano na szpaltach „Czasu”: „Wybory muszą być koniecznie w niedzielę, nie wiemy czy dlatego, że przeciwko obraniu soboty protestowaliby niewątpliwie wyborcy żydowscy, czy też dlatego, by zerwać ostentacyjnie z burżuazyjnym przesądem święcenia dnia świętego". Vide Program Moraczewskiego, „Czas” z 22 XII 1918 r., nr 511, s. 1. 
i funkcjonowanie kontrolował minister spraw wewnętrznych, od którego decyzji przysługiwało komisjom odwołanie do Sądu Najwyższego [dalej: SN]. Nad przestrzeganiem przepisów w danym okręgu nadzór pełnił ponadto okręgowy komisarz wyborczy mianowany przez ministra spraw wewnętrznych ${ }^{51}$. Komisarze pozostawali pod zwierzchnictwem Generalnego Komisarza Wyborczego [dalej: GKW], mianowanego przez Naczelnika Państwa na wniosek rządu ${ }^{52}$. W art. 19 przewidziano, że przewodniczącym głównej komisji wyborczej był prezes sądu okręgowego lub sędzia przez niego powołany. Zgodnie z art. 20 funkcję jego zastępcy sprawował sędzia powołany przez prezesa sądu okręgowego. Na mocy art. 21 pozostałych trzech członków komisji wybierały ze swego grona zarówno rady miejskie — wybór jednego członka, jak i zgromadzenia wójtów powiatu - wybór dwóch członków. W okręgach obejmujących wyłącznie miasto, wyboru dwóch członków komisji dokonywały rady miejskie, jednego wybierały natomiast związki zawodowe. W myśl art. 25 miejscowe komisje wyborcze składały się z przewodniczącego, jego zastępcy i trzech członków. Byli oni powoływani przez główną komisję wyborczą. Przyjęcie przez legislatorów zaprezentowanych regulacji oznaczało, że nie tylko struktura komisji wyborczych, ale również relacje między nimi miały charakter zdecentralizowany. Główne komisje wyborcze działały bowiem niezależnie od siebie, a powzięte przez nie decyzje cechowała duża samodzielność. Częściowe zmiany w ramach przywołanych rozwiązań normatywnych nastapiły w II RP dopiero na podstawie ordynacji wyborczej do Sejmu i Senatu z 28 lipca 1922 r. Były one skutkiem utworzenia wspólnej dla całego kraju Państwowej Komisji Wyborczej. Należy jednak pamiętać, że kompetencje Komisji odnosiły się przede wszystkim do problematyki nowej instytucji prawa wyborczego, jaką były listy państwowe.

Na podstawie art. 31 sprawdzenie praw wyborczych rozpoczynało się od sporządzenia przez naczelnika gminy spisu obywateli, zamieszkujących w poszczególnych miejscowościach gminy, którzy w dniu ogłoszenia wyborów mieli ukończone 21 lat. Do tego spisu obowiązkowo dołączał on spis osób, które nie posiadały praw wyborczych w myśl art. 5 ordynacji. Zgodnie z art. 33 po otrzymaniu spisów od naczelnika gminy, względnie burmistrza, miejscowa komisja badała je, a następnie podejmowała decyzję o ich zatwierdzeniu. To wszystko powodowało, że listę wyborców trzeba było dopiero ułożyć. Dokonywano tego albo przez odpisanie ze spisu ogólnego wszystkich nazwisk z wyjątkiem zamieszczonych w spisie negatywnym, albo przez wykreślenie tych nazwisk ze spisu ogólnego. Na mocy art. 34 komisja miejscowa miała prawo żądać od naczelnika gminy okazania materiałów, na bazie których opracował on spisy mieszkańców. Miała także prawo żądać od niego wyjaśnień w tej sprawie. Zgodnie $\mathrm{z}$ art. 35 komisja ta była zobowiązana najpóźniej do 25. dnia od dnia ogłoszenia

51 Należy zauważyć, że przyjęte przepisy — co odróżnia omawiane przedłożenie od projektów wcześniejszych — wprowadzały przedstawicieli rządu do procesu wyborczego. Regulacje te były jednak zgodne z obowiązującymi wtedy na Starym Kontynencie kanonami prawa konstytucyjnego.

52 Generalnym Komisarzem Wyborczym w okresie wyborów do konstytuanty został B. Sobolewski — prezes Sądu Apelacyjnego w Warszawie (M.P. z 1918 r. nr 217), jego zastępcą był W. Wolter — prezydent Krajowego Sądu Wyższego w Krakowie (M.P. z 1918 r. nr 223). 
wyborów przesłać zaakceptowaną przez siebie listę wyborców do głównej komisji wyborczej i jednocześnie drugi egzemplarz tej listy wyłożyć do wglądu obywateli na osiem godzin dziennie przez pięć dni ${ }^{53}$. W świetle art. 36 każdy obywatel miał prawo przedłożyć reklamację przeciwko liście wyborców. Zgodnie z art. 38 komisja miejscowa — najpóźniej nazajutrz — pisemnie zawiadamiała osoby, wobec których wniesiono reklamację mającą na celu usunięcie ich z listy wyborców. Na podstawie art. 39 osoby, których prawo wybierania podano w wattpliwość, mogły przedkładać dowody na swoją obronę do komisji miejscowej w czasie trzech dni od dnia doręczenia im zawiadomienia. W art. 40 zobligowano komisję miejscowa, aby reklamację w tej kwestii rozstrzygnęła w ciagu trzech dni. Od jej postanowień przysługiwało odwołanie do komisji głównej za pomocą reklamacji złożonej do komisji miejscowej w trakcie 48 godzin od daty doręczenia orzeczenia. Przepis ten dopuszczał też możliwość zgłoszenia kontrreklamacji, ale w przeciwieństwie do reklamacji nie precyzował, w jakim terminie należało to zrobić. Na mocy art. 41 główna komisja wyborcza badała spisy, listy, protesty, reklamacje i kontrreklamacje. W dalszej kolejności ustalała ostateczne listy wyborców i rozsyłała je do komisji miejscowych najpóźniej w 32. dniu od dnia ogłoszenia wyborów. W myśl art. 42 orzeczenia głównej komisji wyborczej mogły zostać zaskarżone do SN, ale tylko ze względu na przekroczenie prawa ${ }^{54}$. Nie budzi wątpliwości, że przyjęcie transparentnych mechanizmów formowania list wyborców, które legislatorzy zawarli w dekrecie, było ważnym elementem procedur normujących przebieg procesu wyborczego ${ }^{55}$. Ich prawidłowe przygotowanie stanowiło bowiem prawną gwarancję realizacji w praktyce zasady równości prawa wyborczego $\mathrm{w}$ aspekcie formalnym.

W świetle art. 43 zgłoszenie kandydatury poselskiej do głównej komisji wyborczej musiało nastapić pisemnie nie później niż 24. dnia od dnia ogłoszenia wyborów, wymagano też, aby było ono podpisane przez 50 wyborców, zamieszkałych w danym okręgu wyborczym (art. 44) ${ }^{56}$. Przytoczony przepis nie nakazywał jednak, by podpisy te były poświadczone przez sąd, notariusza czy urząd gminy ${ }^{57}$. To de facto czyniło ten warunek niemal bezprzedmiotowym. Na mocy art. 45 zgłoszenia były rejestrowane

53 W tym kontekście w „Kurierze Warszawskim” napisano: „Wyborcy! Przypominamy wam, że pilnym waszym obowiązkiem narodowym jest dopilnować swoich praw wyborczych i wziąc udział w wyborze posłów do pierwszego polskiego sejmu ustawodawczego. Macie już tylko cztery dni na sprawdzenie w biurach obwodowych wyborczych, czy wciagnięto was do spisu wyborców, czy nie jesteście pozbawieni należnych wam praw obywatelskich”. Vide Przed wyborami, „Kurier Warszawski” z 9 I 1919 r., nr 9, s. 3.

54 Skargi na orzeczenia w tych sprawach na terenie okręgów wytyczonych w Galicji rozpoznawał Krajowy Sąd Wyższy. Dekret z dnia 19 grudnia 1918 r. o przekazaniu Krajowemu Sądowi Wyższemu w Krakowie niektórych funkcji Sądu Najwyższego, Dz.P.P.P. z 1918 r. nr 20, poz. 64.

55 J. Makowski, omawiając tę kwestię, zauważył: „Należy wszystko uczynić, żeby te listy wyborców odzwierciedlały dokładnie to, co publicystyka francuska zwykła określać wyrażeniem payslégal, winny one więc być sporządzane uczciwie i dokładnie, bez opuszczeń, błędów i fałszerstw". J. Makowski, Zarys prawa wyborczego, Warszawa 1918, s. 26.

56 Vide też S. Kutrzeba, Proporcyonalne głosowanie, Warszawa-Lublin-Łódź-Kraków [b.d.w.], s. 60.

57 Art. 48 projektu przygotowanego w MSW wprowadzał tego rodzaju obostrzenie. Został on jednak wykreślony przez rząd z rozpatrywanego przedłożenia 20 listopada 1918 r. AAN, PRM, t. 4, k. 349, sygn. 20048. 
przez komisję według kolejności ich składania. Numer zgłoszenia automatycznie stawał się numerem listy kandydatów. Przepisy ordynacji nie określały natomiast ani minimalnej, ani maksymalnej liczby kandydatów, których można było umieścić na liście ${ }^{58}$. W myśl art. 47 grupy, które zgłosiły listy kandydatów mogły — najpóźniej 27. dnia od dnia ogłoszenia wyborów - poinformować, że tworzą związek wybor$\mathrm{czy}^{59}$. Omawiany artykuł przewidywał również, że takim związkom przysługiwały prawa jednej grupy ${ }^{60}$. Zgodnie z art. 48 zgłoszenie powinno szeregować kandydatów w porządku pierwszeństwa, w jakim mieli wchodzić do Sejmu. Na podstawie art. 49 należało podać w nim imię i nazwisko, zawód, wiek i miejsce zamieszkania każdego $\mathrm{z}$ nich. Poważnym błędem wydaje się pominięcie $\mathrm{w}$ dekrecie — co nie zdarzało się we wcześniejszych przedłożeniach - obostrzenia dotyczącego wyrażenia zgody przez kandydata, aby zamieścić jego nazwisko na liście ${ }^{61}$. W praktyce oznaczało to, że można było na nią wpisać dowolną osobę nawet wbrew jej woli ${ }^{62}$. Zgodnie z art. 50 ten sam kandydat mógł ubiegać się o mandat „w wielu” okręgach wyborczych. W świetle art. $53 \mathrm{w}$ przypadku zgłoszenia tylko jednej listy kandydatów lub zgłoszenia kilku list, ale obejmujących tyle nazwisk, ile było mandatów do rozdzielenia w danym okręgu, wybory nie odbywały się. Główna komisja wyborcza ogłaszała wówczas, że każda z tych osób uzyskiwała mandat poselski. Art. 54 stanowił z kolei, że w razie zgłoszenia więcej niż jednej listy, o łącznej liczbie kandydatów większej od liczby posłów, którzy mieli zostać wybrani w tym okręgu, główna komisja wyborcza ogłaszała, najpóźniej 32. dnia od dnia ogłoszenia wyborów, wszystkie listy kandydatów.

Głosowanie rozpoczynało się o godzinie ósmej i trwało nieprzerwanie do godziny 22. W myśl art. 69 odbywało się ono za pomocą kart urzędowych. Karty te, zawierające wydrukowane numery list kandydatów, miały być sprzedawane w ciagu pięciu dni przed wyborami po pięć fenigów sztuka (10 halerzy). Nie budzi wątpliwości, że

${ }^{58}$ Wydaje się, że wymiernym skutkiem przyjętego rozwiązania mogła być sytuacja, w której na liście umieszczono by jedynie tylu kandydatów, ile było mandatów do obsadzenia w okręgu lub nawet liczby mniejszej niż wynikająca z regulacji zawartych w dodatku nr 1. Zagrożenie to nasilało się szczególnie w najmniejszych okręgach, gdzie w razie śmierci posła, unieważnienia lub wygaśnięcia jego mandatu, przy założeniu zgłoszenia tylko jednej listy kandydatów, fotel poselski mógł zostać trwale opróżniony. Ostatecznie prawodawcy na mocy Instrukcji umożliwili zgłaszanie większej liczby kandydatów na posłów niż było mandatów do rozdzielenia w danym okręgu. BSGH, Instrukcja..., sygn. 167071.

${ }^{59}$ Legislatorzy nie wskazali natomiast reguł, na podstawie których komisje miały dokonywać repartycji mandatów między listy tworzące ten związek. Uchybienie to zostało przez nich naprawione w Instrukcji. Mandaty na bazie zapisanych w niej postanowien, w takim przypadku, nakazali oni rozdzielać według metody d'Hondta. Ibidem.

${ }^{60}$ M. Rostworowski analizując to zagadnienie stwierdził: „Zgłoszenie związku wyborczego nie jest połączeniem stronnictw, czyli ich koalicją gdyż ta polega na wystawieniu wspólnej listy przez dwa lub kilka stronnictw, przy czym kolejność kandydatów zależy od liczebności stronnictw. Tymczasem związek wystawia tyle list, ile jest stronnictw i nie wyklucza bynajmniej ich konkurencji między sobą". M. Rostworowski, Geneza państwa polskiego, Kraków 1921, s. 184-185.

${ }^{61}$ Ułomność rozpatrywanego rozstrzygnięcia była skutkiem niezrozumiałej decyzji podjętej przez gabinet. W dniu 20 listopada 1918 r. postanowił on bowiem wykreślić z projektu wypracowanego w MSW art. 54, który zawierał takie zastrzeżenie. AAN, PRM, t. 4, k. 349, sygn. 20048.

${ }^{62}$ Postępowanie, o którym mowa, odnotowano choćby w okręgu nr 16 (Warszawa). Vide Przed wyborami, „Kurier Warszawski” z 21 I 1919 r., nr 21, s. 4. 
wprowadzenie tej opłaty godziło w zasadę powszechności prawa wyborczego, ponieważ wyborca mógł nie dysponować kwotą umożliwiającą zakup karty do głosowania. Tak więc, mimo że formalnie miał on prawo wybierania, tracił możliwość oddania głosu. Finalnie ułomność przyjętego rozstrzygnięcia dostrzegli także legislatorzy. Na mocy dekretu z 26 grudnia 1918 r. o zmianach w ordynacji wyborczej do Sejmu Ustawodawczego znieśli zatem kartę urzędową, sankcjonując jednocześnie głosowanie kartami prywatnymi ${ }^{63}$. Głosowanie — regulował to art. 70 - odbywało się w następujący sposób: wyborca podchodził do stołu, przy którym siedziała komisja wyborcza i wymieniał swoje nazwisko. Po sprawdzeniu, czy znajdowało się ono na liście wyborców, otrzymywał kopertę urzędowa, do której wkładał kartę do głosowania ${ }^{64}$. Zakleiwszy kopertę, wręczał ją przewodniczącemu komisji. Przewodniczący, po zweryfikowaniu stempla urzędowego na kopercie, wrzucał ją do urny wyborczej. Równolegle członek komisji prowadzący protokół dokonywał stosownej adnotacji w jego treści. Należy podkreślić, że niezamieszczenie w omawianym przedłożeniu rozwiązań warunkujących wydzielenie osłoniętych miejsc, w obrębie których wyborca mógłby włożyć kartę do koperty, było przykładem wadliwego unormowania zasady tajności głosowania ${ }^{65}$. Pominięcie tego wymogu powodowało bowiem, że wyborca, który nie napisał (ewentualnie nie wydrukował) wcześniej numeru listy kandydatów na karcie do głosowania, musiał to uczynić w obecności wszystkich osób znajdujących się w danym lokalu wyborczym ${ }^{66}$.

Stwierdzenie wyniku głosowania następowało w dwóch etapach. Najpierw prace podejmowała miejscowa komisja wyborcza. Na mocy art. 75 i 76 obliczała, weryfikując jednocześnie ważność kart do głosowania, liczbę głosów oddanych na konkretne listy kandydatów. Następnie komisja sporządzała protokół dokumentujący przedsięwzięte przez nią działania. Protokół ten - po podpisaniu przez członków komisji - był przekazywany wraz z kartami do głosowania oraz listami wyborców do głównej komisji wyborczej. Zgodnie $\mathrm{z}$ art. 80 jej posiedzenie rozpoczynające drugi etap procesu musiało odbyć się najpóźniej na trzeci dzień po głosowaniu. W ordynacji nie wspomniano natomiast, że mandaty miały być rozdzielane między listy kandydatów proporcjonalnie $^{67}$. Co więcej, w przepisach dekretu nie ma informacji, według jakiej

${ }^{63} \mathrm{Na}$ podstawie tego dekretu art. 69 ordynacji uzyskał następujące brzmienie: „Głosowanie odbywa się za pomocą kart do głosowania. Karta ma zawierać jedynie numer listy kandydatów, na którą wyborca oddaje swój głos. Numer może być drukowany, albo pisany". Dekret z dnia 26 grudnia 1918 r. o zmianach w ordynacji wyborczej do Sejmu Ustawodawczego, Dz.P.P.P. z 1918 r. nr 21, poz. 74.

${ }_{64}$ Pierwotnie, zgodnie $\mathrm{z}$ art. 71 ordynacji, wyborca oddawał głos poprzez podkreślenie na karcie numeru listy. Ostatecznie jednak rozwiązanie to - na mocy przeprowadzonej w grudniu 1918 r. nowelizacji przepisów — prawodawcy usunęli z przedłożenia. Ibidem.

${ }_{65}$ Wada ta stanowiła pokłosie decyzji podjętej przez rząd 21 listopada $1918 \mathrm{r}$. Wówczas to bowiem jego członkowie wykreślili z projektu przygotowanego w MSW fragment art. 75. Usunięte przez nich obostrzenie warunkowało istnienie ,osobnego pokoju lub też należycie osłoniętego stołu”. AAN, PRM, t. 4, k. 341 i 361, sygn. 20048.

${ }_{66}$ Adwokat A. Bogucki zalecał zatem, aby wyborcy przynosili wypełnione już karty do głosowania. A. Bogucki, Ordynacja wyborcza do Sejmu Ustawodawczego, Warszawa 1919, s. 18.

${ }^{67}$ Zastosowanie proporcjonalności popierał S. Kutrzeba: „Specjalnie zaś nadaje się ona dla Polski, a to ze względu na jej skład nie jednonarodowy; zabezpieczy prawa reprezentacji mniejszości narodowych obcych: Niemców, Żydów itd., którzy nie będą mogli czynić nam żadnych zarzutów, iż ich upośledzamy, gdy 
metody przeliczania głosów na mandaty komisje miały dokonywać tej operacji. Art. 81 stanowił tylko, że główna komisja wyborcza po obliczeniu głosów oddanych na poszczególne listy przystępowała do repartycji mandatów poselskich wykorzystując przy tym metodę zaprezentowaną w dodatku $\mathrm{nr} 5^{68}$. Na podstawie symulacji matematycznej zamieszczonej we wskazanym dodatku można orzec, że chodziło o metodę d'Hondta $^{69}$. W myśl art. 82 z czynności głównej komisji wyborczej spisywano protokół. Po ustaleniu jego zawartości przewodniczący głównej komisji wyborczej ogłaszał wynik głosowania, a następnie podawał go do publicznej wiadomości (art. 83). Potem, zgodnie $z$ art. 84, wystawiał on dla posłów wybranych w danym okręgu listy wierzytelne ${ }^{70}$. Zgodnie z art. 85 protokół był podpisywany przez członków komisji. Na mocy art. 86 protokół ten wraz z aktami wyborczymi miejscowych komisji wyborczych i kartami do głosowania przesyłano do pierwszego prezesa SN.

Rozdział V normował zagadnienie ważności wyborów. W świetle art. 88 w ciągu 14 dni po ogłoszeniu wyniku głosowania przez główną komisję wyborczą każdy obywatel mógł wnieść protest przeciwko wyborowi konkretnej osoby na posła. Zgodnie z art. 89 przewodniczący tej komisji po otrzymaniu skargi ogłaszał w dzienniku urzędowym państwa i w dzienniku miejscowym, że została ona formalnie przedłożona. Jednocześnie wyznaczał dziesięciodniowy okres, w trakcie którego można było przedkładać zarzuty wobec jej treści. Na mocy art. 90 i 94 o ważności wyborów oprotestowanych decydował na publicznym posiedzeniu SN. Miał na to sześć miesięcy od dnia wyborów. Zgodnie z art. $91 \mathrm{SN}$ - działając w charakterze trybunału wyborczego orzekał w składzie trzech sędziów ${ }^{71}$. Jeśli chodzi natomiast o ważność wyborów nieoprotestowanych, to kwestię tę na podstawie art. 96 rozstrzygał Sejm, najpóźniej w terminie dwóch miesięcy.

Rozdział VI regulował zarówno mechanizmy wygaśnięcia mandatu poselskiego, jak i uzupełnienia składu Sejmu. Mandat zostawał unieważniony (art. 97), jeżeli okazało się, że poseł nie był wybieralny według art. 7 i 8, albo później prawo to utracił. W myśl art. 98 SN mógł unieważnić wybór gdy: zostało stwierdzone, że w danym okręgu mandat poselski uzyskano przy użyciu przekupstwa, wymuszenia, fałszu lub

dostaną tyle mandatów, ile im przypadnie w stosunku do siły liczebnej ich wyborców, zabezpieczy jednak także bez sztucznych kombinacji i prawa reprezentacji mniejszości polskich, np. na Rusi”. S. Kutrzeba, Proporcyonalne głosowanie..., s. 40.

${ }^{68}$ Nie budzi wattpliwości, że problematykę tę — z racji jej znaczenia — legislatorzy powinni uregulować w konkretnym artykule dekretu.

${ }^{69} \mathrm{Na}$ temat tej metody vide A. Esmein, Prawo konstytucyjne, nota biograficzna K.M. Ujazdowski, Warszawa 2013 (reprint wydania z 1921 r.), s. 263.

${ }^{70}$ Oryginalny dokument potwierdzający wybór na posła S. Osieckiego znajduje się w Muzeum Historii Polskiego Ruchu Ludowego, S. Osiecki i F. Kamiński, [brak jednolitej paginacji kart], sygn. 4645.

71 W. Komarnicki chwalił przytoczone rozwiązania: „Cechą charakterystyczną tej ordynacji wyborczej jest wybitny udział w organizacji wyborów organów sądowych, co objaśnia się poza względami bezstronności i autorytetu tych organów, tym także, że w momencie owym organy sądowe, jako istniejące dawniej, działały sprawniej, niż organy dopiero tworzącej się administracji. Zupełnie zresztą słusznie wprowadzono ingerencję sądową do rozstrzygania protestów przeciwko ważności wyborów, oraz zakwestionowania wyborów przez Sejm, właściwie bowiem jest to funkcja z natury swej sądowa”. W. Komarnicki, Polskie prawo..., s. 62. 
jakichkolwiek innych działań zabronionych przez prawo, albo jeżeli w postępowaniu wyborczym przepisy ordynacji nie były przestrzegane. W art. 99 zapisano, że w wypadku, gdy ten sam kandydat został wybrany w więcej niż w jednym okręgu, musiał on — najpóźniej na pierwszym posiedzeniu Izby — podjać decyzję, z którego z nich obejmował mandat. W przeciwnym razie rozstrzygało o tym losowanie dokonywane przez marszałka Sejmu. Zgodnie z art. $100 \mathrm{w}$ sytuacji unieważnienia wyboru posła według art. 98, o ile SN orzekł, że nie mogły być wykorzystane procedury zapisane $\mathrm{w}$ art. 101, minister spraw wewnętrznych zarządzał wybory ponowne w okręgu lub obwodzie, gdzie prawo zostało przekroczone, w okresie 15 dni od ich unieważnienia. Z kolei art. 101 miał zastosowanie we wszystkich pozostałych przypadkach unieważnienia lub ustania mandatu. Na jego mocy główna komisja wyborcza informowała o wstapieniu na miejsce posła, którego mandat wygasł lub został unieważniony, następnego kandydata $\mathrm{z}$ tej samej listy i wystawiała mu list wierzytelny.

W dniu 28 listopada 1918 r., wraz z dekretem o ordynacji wyborczej, J. Piłsudski podpisał również dekret o wyborach do Sejmu Ustawodawczego ${ }^{72}$. Wybory na jego podstawie wyznaczono na dzień 26 stycznia 1919 r. Dekret ten wskazywał także ziemie, na których miały one zostać przeprowadzone. Przyjęcie postanowień, o których mowa, było podyktowane koniecznością dostosowania wykazu terenów objętych procedurami wyborczymi do realiów politycznych ${ }^{73}$. Oczywiste było bowiem, że dodatek nr 1 uwzględniał listę okręgów, która została ułożona bardziej podług oczekiwań normodawców niż faktycznych możliwości prawnych czy też decyzyjnych otwierających się w tej kwestii przed II RP.

W dekrecie zapisano, że wybory odbędą się na większości ziem dawnego zaboru rosyjskiego ${ }^{74}$. Elekcja na tych terenach miała zostać zarządzona we wszystkich okręgach wymienionych $\mathrm{w}$ dodatku $\mathrm{nr} 1$, $\mathrm{z}$ wyjątkiem okręgu $\mathrm{nr} 1$. W przypadku terytorium byłego zaboru austriackiego wybory miały odbyć się w okręgach od $\mathrm{nr} 36$ do nr 46. Na pozostałych obszarach Galicji, które wyszczególniono w ordynacji — chodzi tu o okręgi od $\mathrm{nr} 47$ do $\mathrm{nr} 59$ - na skutek toczących się tam zmagań zbrojnych nie można było ich zorganizować. W związku z tym w miejsce kandydatów, których planowano wybrać w przywołanych okręgach, mieli wejść polscy posłowie reprezentu-

${ }^{72}$ Dekret z dnia 28 listopada 1918 r. o wyborach do Sejmu Ustawodawczego, Dz.P.P.P. z 1918 r. nr 18, poz. 47

${ }^{73}$ Dziennikarze „Głosu” analizując tę kwestię napisali: „W okręgach Galicji Wschodniej pozostaną w mocy dawne mandaty polskie do austriackiej Rady Państwa; przedstawicielstwo zaboru pruskiego ma być ustalone po porozumieniu z przedstawicielami społeczeństwa polskiego w tym zaborze, a więc zapewne wobec oczywistej niemożebności przeprowadzenia tam obecnie wyborów — wypadnie również zachować dawne mandaty, uzupełniając je co do niektórych okręgów niemających przedstawicielstwa polskiego. Sześcioprzymiotnikowy zatem system zostanie zastosowany tylko do ziem byłej Kongresówki i do Galicji Zachodniej. Zastosowanym zostanie tam, gdzie ludność najmniej jest przystosowaną do tak szerokiego korzystania ze swych praw obywatelskich. Niejednolitość systemu przedstawicielstwa zapewne niejednokrotnie będzie w Sejmie lub poza Sejmem użytkowana, jako argument w tych wypadkach, gdy co jest zupełnie możliwe, podział przy głosowaniach nad wieloma wnioskami nastapi według dzielnic”. Vide Zwołanie Sejmu, „Głos” z 30 XI 1918 r., nr 386, s. 1.

74 Poszczególne rozwiązania, które zostały zawarte w tym przedłożeniu ministrowie omówili w dniach 23, 25, 26 i 27 listopada 1918 r. AAN, PRM, t. 4, k. 362, 379 i 394, sygn. 20048. 
jący te ziemie w Izbie Posłów Rady Państwa monarchii austriackiej ${ }^{75}$. Wybory rozpisano też na Śląsku Cieszyńskim, ale nie w dwóch, jak stanowiły przepisy ordynacji, lecz w jednym okręgu wyborczym (nr 35 Cieszyn). Przedstawiciele z dawnego zaboru pruskiego - okręgi od $\mathrm{nr} 60$ do $\mathrm{nr} 70$ - mieli zostać wyłonieni na mocy porozumienia zawartego między władzami odrodzonej RP a zamieszkującą ten region polską społecznością. Legislatorzy zdawali sobie bowiem sprawę, że zadaniem niewykonalnym będzie - przy braku dostatecznie silnej armii — pokonanie na tym terytorium wojsk niemieckich. Na koniec należy zauważyć, że w skład konstytuanty mieli zostać powołani, choć przedłożenie nie precyzowało daty rozpoczęcia tego procesu, także reprezentanci Polaków na Litwie i Rusi.

W dniu 8 stycznia 1919 r. J. Piłsudski podpisał dekret o postanowieniach karnych za przeciwdziałanie wyborom do Sejmu i wykonywaniu obowiązków poselskich ${ }^{76}$. Był to ostatni akt prawny dotyczący kwestii wyborczych, który został przygotowany przez rząd Moraczewskiego. Stało się tak, ponieważ 16 stycznia 1919 r. J. Moraczewskiego na stanowisku premiera zastapił Ignacy Jan Paderewski (bezpartyjny) ${ }^{77}$. Wydarzenia te, mimo że spowodowały znaczące przetasowania na scenie politycznej, nie wpłynęły na zmianę charakteru wyzwań, z którymi musiała zmierzyć się nowa Rada Ministrów. Najważniejsze z nich nadal ogniskowało się wokół problemu przeprowadzenia wyborów do konstytuanty ${ }^{78}$. To niełatwe zadanie przypadło w udziale mianowanemu przez I.J. Paderewskiego na urząd ministra spraw wewnętrznych Stanisławowi Wojciechowskiemu (bezpartyjny) ${ }^{79}$. Ostatecznie pierwsze wybory parlamentarne w II RP zostały uznane zarówno przez liderów poszczególnych stronnictw, jak i opinię publiczną za w pełni uczciwe ${ }^{80}$. Anonimowy autor na łamach „Naprzód” stwierdził: „Wczo-

75 Ostatecznie w okręgu nr 47 (Lwów — miasto), w konsekwencji śmierci posłów reprezentujących dawne okręgi nr V i nr VII, ich granice pokrywały się z obszarem przywołanego okręgu, rozpisano wybory uzupełniające. Odbyły się one 26 stycznia 1919 r. na podstawie przepisów ordynacji do Izby Posłów Rady Państwa.

${ }^{76} \mathrm{Na}$ mocy tego dekretu sądy, w zależności od istoty popełnionego przestępstwa, mogły wymierzyć oskarżonemu nie tylko karę aresztu, ale i więzienia. Dekret z dnia 8 stycznia 1919 r. o postanowieniach karnych za przeciwdziałanie wyborom do Sejmu i wykonywaniu obowiązków poselskich, Dz.P.P.P. z 1919 r. nr 5, poz. 96.

77 M.P. z 1919 r. nr 13. Premier Paderewski oświadczył wówczas: „Pierwszym zadaniem nowego rządu będzie przeprowadzenie wyborów i zwołanie Sejmu, na którym niewątpliwie wypowie się zbiorowa wola naszego narodu”. Vide Deklaracja Paderewskiego, „Kurier Polski” z 17 I 1919 r., nr 13, s. 3.

${ }^{78}$ Członkowie rządu Moraczewskiego podsumowując swoje dokonania w tej materii napisali: ,W bardzo krótkim czasie przygotowaliśmy w zupełności zwołanie Sejmu. Wybory rozpisano na najdemokratyczniejszej podstawie, rozstrzygną one w dniu 26 stycznia 1919 r. walkę o władzę w Polsce. Pierwsze posiedzenie Sejmu może się odbyć przed upływem połowy lutego. Najważniejsze więc nasze zadanie spełnione". Vide Pismo ustępujacego gabinetu do Naczelnika Państwa, ibidem, s. 4.

${ }^{79}$ Minister Wojciechowski w okólniku adresowanym do komisarzy wyborczych stwierdził: „Zadaniem administracji państwa jest dopilnowanie, aby wszyscy wyborcy mogli spełnić swój obywatelski obowiązek w dniu 26 stycznia. Wyznaczam Pana do podjęcia, z bezwzględną bezstronnością, wszystkich środków zabezpieczających spokój i bezpieczeństwo głosujących i całość dokumentów. Należy wszystko tak przeprowadzić, aby zarzut stronniczości czy niedołęstwa nie spadł na administrację państwa i jej funkcjonariuszy". Biblioteka Narodowa, S. Wojciechowski, Moje wspomnienia, t. II, 1918-1922, k. 4, akc. 10398.

${ }^{80}$ Na temat wyniku tych wyborów vide K. Kacperski, System wyborczy do Sejmu i Senatu u progu Drugiej Rzeczypospolitej, Warszawa 2007, s. 107-126. 
rajszy dzień historyczny miał w sobie jakiś odmienny nastrój — czy może robił takie wrażenie w tych dziesiątkach tysięcy, które czuły, że dokonuje się wielkie uroczyste dzieło, że w tych godzinach buduje się wielki gmach - Sejmu polskiego. Zrozumienie doniosłości tej chwili przejawiało się w thumnym udziale ludności, jak też w niezakłóconym spokoju, z jakim we wszystkich lokalach odbywały się wybory"

Ordynacja wyborcza do konstytuanty, którą na polecenie Naczelnika Państwa J. Piłsudskiego wypracował rząd J. Moraczewskiego, nie była wzorcowym aktem prawnym. Nie budzi wątpliwości, że niektóre zawarte w niej regulacje zostały przez legislatorów sformułowane niestarannie. Niejednokrotnie też na skutek pośpiechu, jaki towarzyszył kopiowaniu rozwiązań jurydycznych zamieszczonych w przedłożeniach stanowiących dla nich punkt odniesienia, były one niespójne wewnętrznie, a w kilku przypadkach nawet błędne merytorycznie. Piętno, jakie dokument ten odcisnął na systemie politycznym RP, jest jednak znacznie głębsze niż wynikałoby to jedynie z analizy jego niedoskonałych przepisów. Należy bowiem pamiętać, że zorganizowane na ich podstawie 26 stycznia 1919 r. wybory umożliwiły ukonstytuowanie się Sejmu Ustawodawczego, który skupiał reprezentantów wszystkich warstw i grup społecznych osiadłych na terenach wskrzeszonego państwa. Rozpatrując tę kwestię, trzeba także zaznaczyć, że zasady prawa wyborczego, które zostały wtedy zdefiniowane na forum Rady Ministrów, weszły do kanonu reguł ustrojowych obowiązujących na terytorium Polski nie tylko w latach międzywojnia, ale przede wszystkim, po dostosowaniu ich do wymogów współczesnej demokracji, również w XXI w.

\section{PROBLEMATYKA PRAWA WYBORCZEGO DO KONSTYTUANTY \\ W LATACH 1919-1922}

Oficjalne ogłoszenie wyniku wyborów przeprowadzonych w styczniu 1919 r., wobec nierozstrzygniętego statusu państwowego poszczególnych regionów, które według zamierzeń J. Piłsudskiego, a także kolejnych gabinetów miały wchodzić w skład II RP, nie zakończyło procesu kształtowania się konstytuanty ${ }^{82}$. Co więcej, okoliczności towarzyszące wyłanianiu posłów na obszarach, które były odzyskiwane w latach 1919-1922, wespół ze specyfiką relacji, jakie łączyły zamieszkujące je społeczności z odrodzoną Polską, częstokroć wymuszały zarówno na członkach Izby, jak i istniejących wówczas rządach uchwalenie nowych bądź nowelizację już obowiązujących przepisów prawa.

W pierwszej kolejności wybory, po zakończeniu okupacji tych ziem przez wojska niemieckie, odbyły się 16 lutego 1919 r. w okręgu nr 2 (Suwałki) i 9 marca 1919 r.

${ }^{81}$ Vide Wybory w Krakowie, „Naprzód” z 28 I 1919 r., nr 24, s. 1.

${ }^{82}$ Konstytuanta, po doliczeniu do 291 posłów wybranych w wyborach 28 członków byłej Izby Posłów Rady Państwa, składała się z 319 przedstawicieli II RP. W tym kontekście należy przypomnieć, że posłów $\mathrm{z}$ dawnego zaboru austriackiego wyłoniono na podstawie dekretu o wyborach do Sejmu Ustawodawczego. Inaczej rzecz miała się z 16 parlamentarzystami, którzy wywodzili się z byłego zaboru pruskiego ( 5 z Górnego Ślasska, 9 z Poznańskiego i 2 z Pomorza). W ich przypadku został bowiem wydany w dniu 7 lutego 1919 r. dekret w przedmiocie powołania do Sejmu Ustawodawczego Polaków, którzy w 1918 r. posiadali mandat poselski do parlamentu Rzeszy Niemieckiej, Dz.P.P.P. z 1919 r. nr 14, poz. 193. 
w okręgu nr 20 (Biała Podlaska) ${ }^{83}$. W okręgu nr 2 wszystkie 4 mandaty przypadły w udziale Związkowi Ludowo-Narodowemu [dalej: ZLN] ${ }^{84}$. W okręgu nr 20 po 2 mandaty uzyskały natomiast PSL „Piast” i ZLN, po jednym zaś Polskie Zjednoczenie Ludowe [dalej: PZL] i mniejszość żydowska ${ }^{85}$. W dniu 15 czerwca 1919 r. wybory zorganizowano też w okręgach nr 33 (Białystok) i nr 34 (Bielsk). W przeciwieństwie do wcześniejszych elekcji zostały one rozpisane nie tylko na podstawie stosowanych dotychczas regulacji prawnych, ale także na mocy ustawy w sprawie zmiany niektórych przepisów ordynacji wyborczej z 28 listopada $1918 \mathrm{r} .{ }^{86}$ Ustawę tę opublikowano, po jednomyślnym zaakceptowaniu przez posłów, 15 maja $1919 \mathrm{r} .{ }^{87}$ Artykuł 1 tego przedłożenia stanowił, że w okręgach nr 33 i nr 34 przewodniczących i ich zastępców w ramach głównych komisji wyborczych powoływał prezes sądu okręgowego w Warszawie. Zgodnie $\mathrm{z}$ art. 3 kandydatury poselskie miały być zgłaszane do głównych komisji wyborczych najpóźniej 11. dnia od dnia zarządzenia wyborów. W świetle art. 4 za dzień zarząazzenia wyborów należało uznać datę wydania rozporządzenia przez ministra spraw wewnętrznych ${ }^{88}$. W okręgu nr 33 po 2 mandaty uzyskały ZLN i Narodowe Zjednoczenie Ludowe [dalej: NZL], po jednym natomiast Zjednoczenie Mieszczańskie [dalej: ZM] oraz listy — Chrześcijańsko-Narodowa i mniejszości żydowskiej. W okręgu nr 34 czterema mandatami - po 2 - podzieliły się ZLN i ZM ${ }^{89}$.

Wybory do konstytuanty, mimo że przygotowania związane z ich przeprowadzeniem były zaawansowane, nie odbyły się na Ziemi Cieszyńskiej. Stało się tak na skutek niespodziewanego zajęcia tych terenów przez wojska czechosłowackie ${ }^{90}$. W tej sytuacji poseł Emil Bobrowski (PPS) na 2. posiedzeniu SU 14 lutego 1919 r. złożył wniosek o powołanie w jego skład 7 kandydatów, którzy mieli zostać wybrani w okręgach $\mathrm{nr} 35$ (Cieszyn) i nr 35A (Frydek) ${ }^{91}$. Projektodawca zaproponował, aby za po-

${ }^{83}$ Dekret z dnia 14 stycznia 1919 r. o przedłużeniu terminu wyborów do Sejmu Ustawodawczego w drugim okręgu wyborczym, Dz.P.P.P. z 1919 r. nr 6, poz. 101; dekret z dnia 14 stycznia 1919 r. o przedłużeniu terminu wyborów do Sejmu Ustawodawczego w dwudziestym okręgu wyborczym, Dz.P.P.P. z 1919 r. nr 6, poz. 102.

${ }^{84}$ K. Kacperski, System wyborczy..., s. 126.

85 Ibidem.

${ }^{86}$ Ustawa z dnia 10 maja 1919 r. w sprawie zmiany niektórych przepisów ordynacji wyborczej z dnia 28 XI 1918 r., celem przeprowadzenia wyborów w okręgach 33 i 34, Dz.P.P.P. z 1919 r. nr 40, poz. 294.

${ }^{87} \mathrm{Na}$ mocy decyzji podjętych przez marszałka trzy czytania tej ustawy odbyły się podczas 36 . posiedzenia Izby 10 maja 1919 r.; SU, sprawozdanie stenograficzne [dalej: spr. sten.], ł. XXXVI/58.

${ }^{88}$ Minister Wojciechowski rozporządzenie to wydał 15 maja 1919 r. Rozporządzenie Ministra Spraw Wewnętrznych z dnia 15 maja 1919 r. o wyborach poselskich do Sejmu Ustawodawczego RP w 33 (białostockim) i 34 (bielskim) okręgach wyborczych, Dz.P.P.P. z 1919 r. nr 40, poz. 295.

${ }^{89}$ K. Kacperski, System wyborczy..., s. 126-127.

${ }^{90} \mathrm{~W}$ tym miejscu warto przypomnieć, że 5 listopada 1918 r. PRNKC zawarła umowę z czeskim Komitetem Narodowym. Na podstawie jej treści dokonano prowizorycznego rozgraniczenia przywołanych ziem. Poczynione wówczas ustalenia miały obowiązywać do momentu rozstrzygnięcia statusu państwowego tych terenów przez mocarstwa. Porozumienie, o którym mowa, zostało zaakceptowane przez Główny Komitet Narodowy w Pradze. Druk nr 162.

91 Należy podkreślić, że przedłożona propozycja była sprzeczna z regulacjami zamieszczonymi w dekrecie o wyborach do SU. Zgodnie z jego postanowieniami okręgi te bowiem scalono. SU, spr. sten., 1. II $/ 38-42$. 
słów uznać 6 kandydatów - 3 z PPSD, 2 ze Związku Katolików Śląskich i 1 z PSL „Piast” — zgłoszonych na wspólnej liście przez partie zrzeszające Polaków w okręgu nr 35. Siódmy mandat na gruncie decyzji podjętej przez Polską Radę Narodową dla Księstwa Cieszyńskiego [dalej: PRNKC] miała uzyskać Dorota Kłuszyńska (PPS) w okręgu nr 35 ${ }^{92}$. Wniosek ten marszałek przesłał do Komisji Konstytucyjnej [dalej: KK $]^{93}$. Miesiąc później, 14 marca 1919 r., sprawozdanie z jej prac na 14. posiedzeniu SU przedstawił poseł M. Niedziałkowski (PPS) ${ }^{94}$. W pierwszym rzędzie przeanalizował on możliwość wyłonienia nowych parlamentarzystów bez konieczności organizowania wyborów. W dalszej kolejności rozważył natomiast zasadność zaaprobowania kandydatury D. Kłuszyńskiej jako reprezentantki okręgu nr 35A. Poseł Niedziałkowski stwierdził, że pierwsza z rozpatrywanych kwestii nie wzbudziła na forum KK żadnych obiekcji ani w aspekcie prawnym, ani moralnym. W opinii całej Komisji wszystkie czynności proceduralne w okręgu nr 35 przeprowadzono bowiem zgodnie $\mathrm{z}$ kalendarzem wyborczym. Co więcej, tryumf w wyborach listy kompromisowej, wobec znaczącej przewagi ludności polskiej nad pozostałymi nacjami, był pewny ${ }^{95}$. Wątpliwości w KK, jak zauważył referent, zrodziła za to sprawa przekazania okręgowi $\mathrm{nr} 35 \mathrm{~A}$ mandatu z okręgu nr 35. Ostatecznie jej członkowie zdecydowali, że na ten temat wypowiedzą się dopiero, gdy ententa ureguluje status państwowy spornego terytorium. W tej sytuacji poseł sprawozdawca złożył wniosek o uznanie za posłów Tadeusza Regera, ks. Józefa Londzina, Jerzego Kantora, Ryszarda Kunickiego, Pawła Bobka i Karola Junga. Jednocześnie zaapelował, aby Izba odrzuciła tę część przedłożenia, która dotyczyła okręgu nr $35 \mathrm{~A}^{96}$. Następnie głos zabrali posłowie: Konstanty Kowalewski (ZLN), Bolesław Fichna (Narodowy Związek Robotniczy, NZR), Maciej Rataj (PSL), Jan Załuska (ZLN), Stanisław Osiecki (PSL „Wyzwolenie”) i Władysław Kiernik (PSL „Piast”) ${ }^{97}$. Wszyscy mówcy poparli rozwiązania uformowane na plenum KK. W związku z tym marszałek zarządził głosowanie procedowanego wniosku. Został on jednomyślnie zaakceptowany przez konstytuantę ${ }^{98}$.

W przypadku terenów byłego zaboru pruskiego Sejm Ustawodawczy, biorąc pod uwagę specyfikę okoliczności towarzyszących ich wejściu w skład II RP, postanowił przyjąć zbiór odrębnych przepisów normujących opisywaną problematykę. Dyskusja w tym zakresie została zapoczątkowana wnioskami, które posłowie I. Daszyński (PPS) oraz Wojciech Korfanty (ZLN) wnieśli w trakcie 2. posiedzenia SU w dniu 14 lutego 1919 r. ${ }^{99}$ Poseł Daszyński w forsowanej wówczas uchwale wezwał rząd, ,aby bezzwłocznie po ustaniu przeszkód, wywołanych operacjami wojennymi” ogłosił wybo-

92 Podobny wniosek zgłosił wtedy również poseł W. Korfanty. Ibidem, ł. II/42-43.

93 Ibidem, 1. II/38 i 45.

94 Ibidem, ł. XIV/696.

$95 \mathrm{~W}$ okręgu nr 35 jeden mandat miał też uzyskać kandydat mniejszości niemieckiej. Ibidem, 1. XIV/ 697-699.

\footnotetext{
96 Ibidem, 1. XIV/700.

97 Ibidem, 1. XIV/700-708.

98 Ibidem, 1. XIV/710.

99 Ibidem, 1. II/37 i 43-44.
} 
ry na obszarze dawnego zaboru pruskiego ${ }^{100}$. Poseł Korfanty zaproponował z kolei, aby z tych ziem weszło do konstytuanty, oprócz 16 posłów do parlamentu Rzeszy Niemieckiej, którzy uzyskali mandaty na mocy dekretu z 8 lutego 1919 r., jak też 71 członków Naczelnej Rady Ludowej [dalej: NRL] i Komisariatu NRL, wybranych 5 grudnia 1918 r. przez Sejm Dzielnicowy w Poznaniu ${ }^{101}$. Jego zdaniem wybory posłów miały odbyć się natomiast „W przeciagu czterech tygodni po przyłączeniu tej dzielnicy" do Polski ${ }^{102}$. Przedłożenia te marszałek skierował do KK ${ }^{103}$.

Dysputa na ten temat była kontynuowana podczas 26. posiedzenia SU 5 kwietnia 1919 r. ${ }^{104}$ Konkluzje w tej sprawie jako referent sprawozdania KK zaprezentował poseł W. Kiernik (PSL „Piast”). W pierwszym rzędzie odniósł się do projektów, które zgłosili posłowie Daszyński i Korfanty. Relacjonując przebieg debaty, która wywiązała się na kanwie ich treści, przyznał, że jej uczestnikom nie udało się wypracować rozwiązania unifikującego obie przedstawione koncepcje. Jednocześnie zauważył, że w toku obrad Komisji większość posłów, chcąc przełamać rodzący się w tym względzie impas, opowiedziała się za szybkim rozpisaniem wyborów na terytorium Księstwa Poznańskiego. W dalszej części wystapienia skoncentrował się on na kwestii zorganizowania wyborów na tych terenach. Analizując tę materię, stwierdził, że KK przygotowała projekt ustawy modyfikujący niektóre przepisy ordynacji. Korekta zawartych w niej norm miała objąc zarówno prawo wybierania, strukturę wewnętrzną komisji wyborczych, mechanizmy formowania list wyborców, jak i spis okręgów wyborczych. W dyskusji na forum Izby udział wzięli posłowie: M. Niedziałowski (PPS), Antoni Stychel (ZLN) i Stanisław Nowicki (NZR) ${ }^{105}$. Wszyscy mówcy poparli założenia rozpatrywanego aktu prawnego. Marszałek zarządził zatem najpierw drugie, a potem trzecie czytanie tego projektu. Ostatecznie posłowie jednomyślnie zaaprobowali wniosek autorstwa $\mathrm{KK}^{106}$.

Artykuł 1 ustawy stanowił, że jej przepisy obowiązywały wyłącznie na wolnych od okupacji niemieckiej ziemiach polskich wchodzących w skład dawnego zaboru pruskiego, w tym zwłaszcza na terenach Księstwa Poznańskiego. W świetle art. 2 terytorium, na którym planowano przeprowadzić wybory, podzielono na 4 okręgi wyborcze: nr I (Mogilno) - 10 mandatów $^{107}$, nr II (Gniezno) - 11 mandatów, nr III (Poznań) - 12 mandatów i nr IV (Ostrów) - 9 mandatów. W dalszej kolejności prawodawcy

100 Ibidem, 1. II/37.

101 Ibidem, 1. II/43-44.

102 Ibidem.

103 Ibidem, 1. II/45.

104 Ibidem, 1. XXVI/3-8.

105 Ibidem, 1. XXVI/8-13. Druk nr 305.

106 Ustawa z dnia 5 kwietnia 1919 r. w przedmiocie zmiany niektórych przepisów ordynacji wyborczej objętej dekretami poz. 46 i 47 nr 18 Dziennika Praw Państwa Polskiego z dnia 6 grudnia 1918 r., w celu przeprowadzenia wyborów posłów do Sejmu Ustawodawczego RP z części ziem polskich byłego zaboru pruskiego, Dz.P.P.P. z 1919 r. nr 30, poz. 253.

107 Ostatecznie wybory w tym okręgu nie odbyły się. Stało się tak, ponieważ Niemcy wciąż zajmowali położone w jego granicach miasta. Oficjalnie polskie władze jako powód odstapienia od aktu głosowania podały jednak zarejestrowanie tylko jednej listy kandydatów. Mowa tu o liście Zjednoczenia Stronnictw Narodowych. Vide Do urny wyborczej, „,Dziennik Poznański” z 31 V 1919 r., nr 124, s. 1. 
zmienili regulacje zapisane w art. 4 ordynacji. Dzięki temu wojskowi w służbie czynnej mogli wziąć udział w głosowaniu, jeśli nie znajdowali się poza obszarem wyborów, który został wskazany w art. $2^{108}$. Następnie legislatorzy znowelizowali art. 8 ordynacji. Na mocy art. 5 zdecydowali, że nie będzie on obejmował członków i urzędników Komisariatu oraz Podkomisariatów NRL zaboru pruskiego. Co więcej, postanowienia zamieszczone w art. 9 i 10 ordynacji nie miały zastosowania wobec komisarzy i podkomisarzy NRL oraz profesorów wyższych uczelni. Zgodnie z art. 6 główne komisje wyborcze składały się z 5 członków, z których 2 wybierali delegaci rad miejskich miast powiatowych, 3 zaś delegaci wszystkich innych gmin okręgu. W świetle art. 7 dzień wyborów miał być wyznaczony najpóźniej na 40. dzień po dniu zarządzenia i ogłoszenia wyborów. Według art. 8 ukonstytuowanie się głównych komisji wyborczych odbywało się maksymalnie w piątym dniu po dniu zarządzenia wyborów. Na podstawie art. 9 spisy obywateli naczelnicy gmin sporządzali do 10. dnia od dnia zarządzenia wyborów i najpóźniej 11. dnia, dostarczali je do miejscowych komisji wyborczych. Komisje te musiały w ciagu kolejnych trzech dni zbadać ich zawartość, a potem ułożyć listę wyborców. W trakcie dalszych 24 godzin jeden egzemplarz zatwierdzonej listy przesyłały do głównej komisji wyborczej, drugi natomiast wykładały do wglądu obywateli na trzy dni, aby mogli oni w tym czasie wnosić ewentualne reklamacje dotyczące jej treści. W art. 10 nakazano, aby główna komisja wyborcza najpóźniej 30. dnia od dnia ogłoszenia wyborów zwróciła ustaloną ostatecznie listę wyborców miejscowym komisjom wyborczym. W myśl art. 11 kandydatury poselskie mogły być zgłaszane do głównej komisji wyborczej najpóźniej 20. dnia od dnia ogłoszenia wyborów. Zgodnie z art. 12 komisja ta ogłaszała najpóźniej 30. dnia od dnia ogłoszenia wyborów listy kandydatów pod warunkiem, że nie zachodziły tu przesłanki wymienione w art. 53 ordynacji. Art. 13 stanowił, że z chwilą wystawienia wybranym posłom listów wierzytelnych wygasały mandaty tych członków Izby, a dawnych posłów do parlamentu Rzeszy Niemieckiej z terytorium Księstwa Poznańskiego, którzy zostali powołani w jej skład na mocy dekretu z 8 lutego 1919 r. Zgodnie z art. 14 pozostałe przepisy zapisane w ordynacji z 28 listopada obowiązywały podczas przygotowywanej wtedy elekcji. Wybory w Wielkopolsce odbyły się 1 czerwca 1919 r. ${ }^{109} \mathrm{~W}$ ich rezultacie wszystkie 42 mandaty uzyskała lista Zjednoczenia Stronnictw Narodowych ${ }^{110}$.

108 Zgodnie z art. 4 rozporządzenia ministra spraw wewnętrznych wojskowi w służbie czynnej mogli głosować w tym obwodzie głosowania, w którym znajdowali się od przedednia złożenia list. Rozporządzenie Ministra Spraw Wewnętrznych z dnia 18 kwietnia 1919 r. o wyborach poselskich do Sejmu Ustawodawczego z części ziem polskich b. zaboru pruskiego, Dz.P.P.P. z 1919 r. nr 33, poz. 270.

109 Ibidem. Wybory te zostały zbojkotowane przez partie reprezentujące Niemców. Ich decyzja miała pokazać, że do momentu formalnego rozstrzygnięcia przez mocarstwa statusu państwowego Wielkopolski nie zaaprobują oni przekazania tych ziem pod zwierzchnictwo Polski. Vide Wybory do Sejmu, „Dziennik Poznański” z 5 VI 1919 r., nr 128, s. 1.

${ }^{110}$ W jej skład weszli kandydaci: Centrum Obywatelskiego, Narodowego Stronnictwa Robotników, Stronnictwa Demokratyczno-Narodowego, Stronnictwa Mieszczańskiego i Narodowego Stronnictwa Ludowego. Vide Zawarcie kompromisu wyborczego, „Kurier Poznański” z 14 V 1919 r., nr 110, s. 1. W następstwie tych wyborów wygasły mandaty dziewięciu posłów. T. Rzepecki, Sejm Rzeczypospolitej Polskiej 1919 roku, Poznań 1920, s. 234-246. 
W dniu 21 lipca 1919 r. w trakcie 74. posiedzenia konstytuanty poseł ks. Kazimierz Lutosławski (ZLN) złożył do laski marszałkowskiej, będący dopełnieniem ustawy z 5 kwietnia 1919 r., projekt ustawy o uzupełniających wyborach do Sejmu Ustawodawczego z dalszych części byłego zaboru pruskiego ${ }^{111}$. Wniosek ten marszałek przekazał do $\mathrm{KK}^{112}$. Sprawozdanie z jej prac na 83. posiedzeniu SU 1 sierpnia $1919 \mathrm{r}$. zaprezentował poseł Władysław Seyda $(Z L N)^{113}$. Referent stwierdził, że Komisja jednogłośnie poparła propozycję kontynuacji procesu wyborczego na mocy postanowień ordynacji z 28 listopada. Jednocześnie, chcąc zrealizować postulaty przedstawione przez posłów podczas omawianych obrad, zarekomendował zmianę niektórych jej przepisów. Zgodnie z art. 2 rozpatrywanego przedłożenia okręgi wyborcze na terenach oswobadzanych spod okupacji niemieckiej miały być tworzone dekretem rządu, wydawanym na wniosek zastępcy Generalnego Komisarza Wyborczego [dalej: ZGKW], przy zachowaniu zasadniczego stosunku jeden poseł na 50 tys. osób. Okręgi te, zgodnie z procedowanym aktem prawnym, liczyły od 7 do 13 mandatów. W myśl art. 3 główne komisje wyborcze należało formować zależnie od warunków miejscowych uchwałą Rady Ministrów wydawaną na wniosek ZGKW. W świetle art. 4 obostrzenia zawarte w art. 8 ordynacji nie dotyczyły, identycznie jak w przypadku Księstwa Poznańskiego, członków i urzędników Komisariatu oraz Podkomisariatów NRL. Na bazie tego samego przepisu ograniczenia zamieszczone w art. 9 i 10 ordynacji nie obejmowały komisarzy i podkomisarzy NRL oraz profesorów wyższych uczelni. W art. 5 zapisano, że wybory miały być zarządzane w danym okręgu niezwłocznie po zakończeniu okupacji jego ziem, zaś dzień głosowania powinien być wyznaczony nie później niż w ciągu 80 dni po ustapieniu zarządu niemieckiego. $\mathrm{Na}$ podstawie art. 6 funkcję GKW powierzono mianowanemu przez rząd ZGKW ${ }^{114}$. Art. 7 przewidywał, że z chwilą wystawienia wybranym posłom listów wierzytelnych wygasały mandaty tych członków Izby, a dawnych posłów do parlamentu Rzeszy Niemieckiej, którzy zostali powołani w jej skład na mocy dekretu z 8 lutego 1919 r. Projekt ten nie wzbudził w Izbie kontrowersji. W związku z tym marszałek zarządził jego drugie i trzecie czytanie. Finalnie został on zaakceptowany przez wszystkich uczestników głosowania115.

Kolejna odsłona postępowania wyborczego nastapiła rok później. Rada Ministrów pod przywództwem Leopolda Skulskiego (NZL) 1 marca 1920 r. wydała rozporządzenie, na kartach którego dokonała podziału województwa pomorskiego na okręgi wyborcze $^{116}$. Przepisy zawarte $\mathrm{w}$ tym rozporządzeniu dzieliły wskazane terytorium na

111 SU, spr. sten., ł. LXXIV/20.

112 Ibidem.

113 Ibidem, ł. LXXXIII/121-124, druk nr 954.

114 Został nim członek NRL W. Wyczyński. C. Demel, Uzupetniajace wybory do Sejmu w Wielkopolsce 1 czerwca 1919 r., „Studia i materiały do Dziejów Wielkopolski i Pomorza”, Warszawa-Poznań 1976, z. 1, s. 159.

115 SU, spr. sten., ł. LXXXIII/124. Ustawa z dnia 1 sierpnia 1919 r. o uzupełniających wyborach do Sejmu Ustawodawczego z dalszych części b. zaboru pruskiego, Dz.P.P.P. z 1919 r. nr 65, poz. 393.

116 Rozporządzenie Rady Ministrów z dnia 1 marca 1920 r. w przedmiocie podziału Województwa Pomorskiego na okręgi wyborcze, Dz.U. z 1920 r. nr 20, poz. 111. 
2 okręgi: nr I (Kościerzyna) — 9 mandatów i nr II (Grudziądz) — 11 mandatów. Tego samego dnia minister spraw wewnętrznych $\mathrm{S}$. Wojciechowski podpisał też rozporządzenie o uzupełniających wyborach do Sejmu Ustawodawczego z dalszych części byłego zaboru pruskiego ${ }^{117}$. Zgodnie $\mathrm{z}$ jego postanowieniami zarządził on na tych terenach wybory poselskie na dzień 2 maja 1920 r. ${ }^{118}$ Wybory na Pomorzu odbyły się bez żadnych komplikacji ${ }^{119}$. W ich rezultacie 9 mandatów uzyskało Narodowe Stronnictwo Robotników [dalej: NSR], 6 mniejszość niemiecka, 4 ZLN, jeden zaś PSL ${ }^{120}$.

Należy przypomnieć, że w okresie pełnomocnictw Izby wybory nie zostały przeprowadzone na Kresach Wschodnich. Stało się tak, mimo że pierwsze wnioski zawierające postulat uregulowania tego zagadnienia posłowie Daszyński (PPS) i ks. Lutosławski (ZLN) wnieśli już na 2. posiedzeniu SU 14 lutego 1919 r. ${ }^{121}$ Poseł Daszyński w zgłoszonej wtedy uchwale wezwał rząd, ,,aby bezzwłocznie przedłożył Sejmowi projekt ustawy wyborczej, mocą której wschodnie ziemie polskie, nieobjęte dotychczasową ustawą wyborcza, mają wybrać posłów na Sejm"122. Poseł ks. Lutosławski zaprezentował z kolei następujący wniosek: „Sejm Rzeczypospolitej poleca Komisji Konstytucyjnej opracować i przedstawić Izbie do uchwalenia projekt ustawy o uzupełnieniu składu osobistego Sejmu Ustawodawczego przedstawicielami ludności polskiej Kresów Wschodnich" "23. Obie uchwały marszałek odesłał do $\mathrm{KK}^{124}$. W dniu 8 kwietnia 1919 r. w trakcie 28. posiedzenia SU posłowie zapoznali się ze sprawozdaniem, jakie w tej kwestii przygotowała Komisja ${ }^{125}$. Poseł S. Osiecki (PSL „Wyzwolenie”) najpierw odczytał uchwały, których treść została uformowana na plenum KK. Pierwsza z nich, którą zaaprobowała większość członków tego gremium, brzmiała: „Wzywa się rząd, aby najdalej do końca kwietnia r.b. w porozumieniu z przedstawicielstwem społeczeństwa polskiego na Litwie i Rusi przedłożył Sejmowi do zatwierdzenia projekt składu osobistego tymczasowego sejmowego

117 Rozporządzenie Ministra Spraw Wewnętrznych z dnia 1 marca 1920 r. o uzupełniających wyborach do Sejmu Ustawodawczego z dalszych części b. zaboru pruskiego, Dz.U. z 1920 r. nr 20, poz. 112.

118 Ibidem. Do rozporządzenia została dołączona Instrukcja do ordynacji wyborczej do Sejmu Ustawodawczego. Zawarte w niej regulacje odnosiły się do 37 przepisów ordynacji. Instrukcja z 1 marca 1920 r. do ordynacji wyborczej do Sejmu Ustawodawczego z dnia 28 listopada 1918 r. (Dz.Pr. nr 18 p. 46) ze zmianami wynikającymi z dekretów z dn. 19 i 26 grudnia 1918 r. (Dz.Pr. nr 20 p. 63 i nr 21 p. 74) oraz z ustawy z dnia 1 sierpnia 1919 r. o uzupełniających wyborach z dalszych części b. zaboru pruskiego (Dz.Pr. nr 65 p. 393), Dz.U. z 1920 r. nr 20, poz. 113.

119 W okręgu nr I (Kościerzyna) zgłoszono 7 list kandydatów, w okręgu nr II (Grudziądz) zarejestrowano ich 9; mowa o listach: Stronnictwa Chrześcijańsko-Ludowego, Narodowo-Chrześcijańskiego Stronnictwa Robotników, NSR, PSL, ZLN, PPS i mniejszości niemieckiej (jedna w okręgu nr I i dwie w okręgu nr II). Vide Wybory do Sejmu na Pomorzu, „Dziennik Bydgoski” z 30 IV 1920 r., nr 98, s. 1.

${ }^{120} \mathrm{~W}$ następstwie tych wyborów wygasły mandaty 2 posłów. Vide Ostateczny wynik wyborów na Pomorzu, „Dziennik Bydgoski” z 15 V 1920 r., nr 109, s. 1. Należy zauważyć, że Śląsk w Izbie przez cały okres jej pełnomocnictw reprezentowali Polacy legitymujący się mandatem do parlamentu Rzeszy Niemieckiej. Vide W. Musialik, Górnoślazacy w parlamentach II Rzeczypospolitej (1919-1939), Opole 2004.

121 SU, spr. sten., 1 . II/37-38 i 44.

122 Ibidem, 1. II/37-38.

123 Ibidem, ł. II/44.

124 Ibidem.

${ }^{125}$ Ibidem, 1. XXVIII/19, druk nr 322. 
przedstawicielstwa ludności polskiej z ziem wschodnich w ilości 16 przedstawicieli”"126. Druga natomiast — wniesiona jako wniosek mniejszości — stanowiła, że: „Sejm Ustawodawczy, nie widząc możliwości powoływania posłów do Sejmu na podstawach innych, niż powszechne głosowanie całej ludności miejscowej, wypowiada się za koniecznością przeprowadzenia wyborów sejmowych według zasad ordynacji wyborczej z dnia 28 listopada 1918 r. z tych ziem na wschodzie, które zgodnie z wolą mieszkańców zostaną przyłączone do Rzeczypospolitej Polskiej" ${ }^{127}$. W dalszej części przemowy poseł Osiecki opowiedział się za przyjęciem drugiego z procedowanych rozwiązań. Poseł Władysław Jabłonowski (ZLN) stwierdził, że reprezentanci Kresów musząjak najszybciej znaleźć się w parlamencie. Dlatego też zachęcał posłów do poparcia uchwały zaakceptowanej przez $\mathrm{KK}^{128}$. Poseł Kazimierz Czapiński (PPS), będąc zwolennikiem wypracowanych już wzorców partycypacji politycznej, podzielił stanowisko wyrażone przez S. Osieckiego ${ }^{129}$. Icchak Grünbaum (Tymczasowa Żydowska Rada Narodowa) postulował, aby w głosowaniu na terenach Litwy i Rusi mogła wziać udział także ludność niepolska, która uznawała się za obywateli II RP ${ }^{130}$. Poseł ks. Lutosławski (ZLN) przypomniał, że posłowie wyłonieni na mocy pierwszego projektu zasiadaliby w ławach Izby tylko do momentu ogłoszenia wyniku wyborów ${ }^{131}$. Poseł Niedziałkowski (PPS) zaapelował z kolei o przestrzeganie, wytyczonych normami ordynacji, standardów jurydycznych ${ }^{132}$. Poseł referent Witold Kamieniecki (PZL) przekonywał natomiast, że mechanizm prawny zamieszczony w tekście uchwały forsowanej przez kluby prawicy i centrum nie był obarczony błędami rzeczowymi. Finalnie jednak, w obliczu wątpliwości proceduralnych, poprosił marszałka o odesłanie tego przedłożenia do $\mathrm{KK}^{133}$. Sejm w głosowaniu usankcjonował tę propozycję ${ }^{134}$. Wniosek ten nie został ponownie uwzględniony w porządku obrad Izby ${ }^{135}$.

Ostatecznie omawiana kwestia została rozstrzygnięta wyłącznie w przypadku Ziemi Wileńskiej. Jednak stało się to nie na mocy przepisów prawa wyborczego, lecz na podstawie decyzji politycznych powziętych zarówno przez wybrany 8 stycznia $1922 \mathrm{r}$. Sejm Wileński, jak i Sejm Ustawodawczy ${ }^{136}$. W odpowiedzi na przegłosowaną 20 lu-

${ }^{126}$ Wniosek ten popierali posłowie prawicy i centrum. SU, spr. sten., ł. XXVIII/20.

127 Uchwałę tę zgłosili posłowie lewicy. Ibidem.

128 Ibidem, 1. XXVIII/22-23.

129 Ibidem, 1. XXVIII/26-31.

130 Ibidem, 1. XXVIII/32.

131 Ibidem, 1. XXVIII/37.

132 Ibidem, 1. XXVIII/39-40.

133 Ibidem, 1. XXVIII/41-42.

134 Ibidem, ł. XXVIII/43.

135 W drugiej połowie 1919 r. posłowie prowadzili też dyskusję, której istota dotyczyła wyłonienia specjalnego organu stanowiącego zinstytucjonalizowane przedstawicielstwo ziem byłego Księstwa Litewskiego. Członkowie tego ciała mieli według zamysłu zwolenników omawianego pomysłu, którzy wywodzili się z klubów prawicy i centrum, formalnie zdecydować o przyszłości prawnej tych terenów. SU, spr. sten., ł. LX/77-78, ł. LXXXII/102-120, ł. LXXXIII/5-13, ł. XCIII/39, ł. CII/51-61 i ł. CIII/3-40. Druki numer: $746,900,1126$ i 1176.

136 SU, spr. sten., ł. CCLX/46-76 ił. CCLXI/4-34. Vide też A. Srebrakowski, Sejm Wileński 1922 roku: idea i jej realizacja, „Acta Universitatis Wratislaviensis”, „Historia”, t. XCIX, Wrocław 1995. 
tego 1922 r. przez Sejm Wileński uchwałę o przyłączeniu Ziemi Wileńskiej do Polski posłowie na 292. posiedzeniu konstytuanty 24 marca 1922 r. jednogłośnie zaaprobowali dwie uchwały: o objęciu władzy państwowej w Ziemi Wileńskiej przez Rząd Rzeczypospolitej Polskiej oraz w sprawie przyjęcia w skład Sejmu Ustawodawczego delegacji Sejmu Wileńskiego. Zgodnie z postanowieniami zawartymi w drugiej z tych uchwał liczba członków Sejmu Ustawodawczego powiększyła o 20 przedstawicieli Sejmu Wileńskiego ${ }^{137}$.

Inicjatywy prawodawcze, które były realizowane na przestrzeni lat 1918-1922 w zakresie problematyki wyborczej, umożliwiły wyłonienie pierwszego parlamentu w dziejach II RP ${ }^{138}$. Analizując przebieg tego procesu, należy podkreślić, że istotne różnice dotyczące mechanizmów kreacji najważniejszych instytucji politycznych, które uwidoczniły się w ramach prowadzonej w tym okresie dysputy ustrojowej, nie wpływały na decyzje podejmowane przez reprezentantów poszczególnych partii uczestniczących w obradach organów formujących zasady regulujące elekcję posłów. W trakcie dyskusji odbywających się czy to na forum rządu, czy też na plenum Sejmu lub w KK, kierowali się oni bowiem nie tyle doraźnymi interesami danego stronnictwa, ile znajomością procedowanych zagadnień, ewentualnie specyfiką konkretnych terenów, które w kolejnych kwartałach miały zostać objęte procedurami wyborczymi. Dzięki temu posiedzenia ciał kształtujących prawo wyborcze do konstytuanty charakteryzowały się wysokim, nastawionym na znalezienie koncyliacyjnych konkluzji normatywnych, poziomem rozważań jurydycznych. Nie budzi wątpliwości, że działania te, biorąc pod uwagę nie tylko ich znaczenie państwowotwórcze, ale i społeczne, zapisały się w historii Polski.

BIBLIOGRAFIA

ŹRÓDŁA

Archiw um Akt Nowy ch w Warszawie

Prezydium Rady Ministrów. Protokoły z posiedzeń Rady Ministrów 18 XI-31 XII 1918 r., t. 4 (maszynopis).

B ibli oteka Narodowa w W a s zawie

Wojciechowski S., Moje wspomnienia, t. II, 1918-1922 (rękopis).

${ }_{137}$ Uchwała Sejmu Wileńskiego z 20 lutego 1922 r. w przedmiocie przynależności państwowej Ziemi Wileńskiej, Dziennik Urzędowy Tymczasowej Komisji Rządzącej z 9 III 1922 r., nr 7, nr 486; SU, spr. sten., 1. CCXC/69-70 i ł. CCXCII/3-13; uchwała Sejmu Ustawodawczego z dnia 24 marca 1922 r. o objęciu władzy państwowej w Ziemi Wileńskiej przez Rząd Rzeczypospolitej Polskiej, Dz.U. z 1922 r. nr 20, poz. 162; uchwała Sejmu Ustawodawczego z dnia 24 marca 1922 r. w sprawie przyjęcia w skład Sejmu Ustawodawczego delegacji Sejmu Wileńskiego, Dz.U. z 1922 r. nr 20, poz. 163.

${ }^{138}$ W dniu otwarcia obrad przez konstytuantę poseł M. Rataj napisał: „Niezapomniana chwila. Jest Polska, jest Sejm — jej przedstawicielstwo. Wtłoczony w masę, czułem się jednak dumny i szczęśliwy, iż jestem jednym z tych, którzy mają budować odrodzone państwo". M. Rataj, Pamiętniki (1918-1927), do druku przygotował J. Dębski, Warszawa 1965, s. 37. 
B iblioteka Sejmowa W W a s zawie

Druki urzędowe Sejmu Ustawodawczego 1919-1922 (maszynopis).

Dziennik Praw Państwa Polskiego 1918-1919 (maszynopis).

Dziennik Urzędowy Tymczasowej Komisji Rządzącej 1922 (maszynopis).

Dziennik Ustaw Rzeczypospolitej Polskiej 1919-1939 (maszynopis).

Monitor Polski. Dziennik Urzędowy Rzeczypospolitej Polskiej 1918-1919 (maszynopis).

Sprawozdania stenograficzne z posiedzeń Sejmu Ustawodawczego 1919-1922 (maszynopis).

B ibli oteka Szkoły Głównej Handlowej w Warszawie

Instrukcja do ordynacji wyborczej do Sejmu Ustawodawczego (maszynopis).

Muzeum Historii Polskiego Ruchu Ludowegow Warszawie

Stanisław Osiecki i Franciszek Kamiński (częściowo rękopis, częściowo maszynopis).

Z a kład Narodowy im. Os s olińs kich we Wrocławiu

Trzaska-Chrząszczewski A., Wspomnienia i rozważania z lat 1887-1957, t. 1, 1887-1922 (maszynopis).

\section{PIŚMIENNICTWO}

Ajnenkiel A., Spór o model parlamentaryzmu polskiego do roku 1926, Książka i Wiedza, Warszawa 1972.

Bartoszewicz J., Zasada wyborcza dla Sejmu Konstytucyjnego, „Gazeta Warszawska” z 29 XI 1918 r., nr 14.

Bogucki A., Ordynacja wyborcza do Sejmu Ustawodawczego, Księgarnia E. Wende i Spółka, Warszawa 1919.

Bogusławski A., O ordynacji wyborczej (objaśnienie ogłoszonej ordynacji wyborczej), Drukarnia Jana Buriana, Warszawa 1918.

Buczkowski J., Podstawowe zasady prawa wyborczego III Rzeczypospolitej, Wydawnictwo UMCS, Lublin 1998.

Cybichowski Z., Polskie prawo państwowe, t. I, Seminarium Prawa Publicznego Uniwersytetu Warszawskiego, Warszawa 1929.

Czego żądać od rzqdu, „Wyzwolenie” z 10 XI 1918 r., nr 45.

Deklaracja Paderewskiego, „Kurier Polski” z 17 I 1919 r., nr 13.

Demel C., Uzupetniajace wybory do Sejmu w Wielkopolsce 1 czerwca 1919 r., „Studia i materiały do dziejów Wielkopolski i Pomorza”, Polskie Towarzystwo Historyczne, Warszawa-Poznań 1976, nr 1.

Do urny wyborczej, „Dziennik Poznański” z 31 V 1919 r., nr 124.

Esmein A., Prawo konstytucyjne, nota biograficzna K.M. Ujazdowski, Wydawnictwo Sejmowe, Warszawa 2013 (reprint wydania z 1921 r.).

Garlicki A., Józef Pitsudski 1867-1935, Czytelnik, Warszawa 1988.

Hełczyński B., Józef Pitsudski jako Naczelnik Państwa (listopad 1918-grudzień 1922), „Niepodległość”, t. 9, Instytut Józefa Piłsudskiego, Londyn-Nowy York 1974.

Ilski Z., Formuła wyborcza u progu niepodległej Polski (do 1922 r.), Wydawnictwo Adam Marszałek, Toruń 2013.

Jodko-Narkiewicz W., Jaka powinna być ordynacja wyborcza do przyszłego Sejmu polskiego?, Drukarnia Towarzystwa Akcyjnego S. Orgelbranda Synów, Warszawa 1918. 
Kacperski K., Koncepcje systemu wyborczego do Sejmu na ziemiach Królestwa Polskiego w latach 1917-1918, Wydawnictwo Sejmowe, Warszawa 2018.

Kacperski K., System wyborczy do Sejmu i Senatu u progu Drugiej Rzeczypospolitej, Wydawnictwo Sejmowe, Warszawa 2007.

Kobiety a Sejm, „Jedność Robotnicza” z 17 XI 1918 r., nr 46.

Kobiety a wybory do Sejmu, „Zorza” z 19 I 1919 r., nr 3.

Komarnicki W., Polskie prawo polityczne (geneza i system), Księgarnia F. Hoesicka, Warszawa 1922.

Kronika polityczna, „Robotnik” z 19 XI 1918 r., nr 303.

Kumaniecki K.W., Odbudowa państwowości polskiej. Najważniejsze dokumenty: 1912-styczeń 1924, Księgarnia J. Czerneckiego, Kraków 1924.

Kutrzeba S., Proporcyonalne głosowanie, Gebethner i Wolff, Warszawa-Lublin-Łódź-Kraków [b.d.w.].

Makowski J., Zarys prawa wyborczego, Księgarnia F. Hoesicka, Warszawa 1918.

Moszczeńska I., Kobiety na arenie politycznej, „Głos” z 27 XI 1918 r., nr 383.

Musialik W., Górnoślazacy w parlamentach II Rzeczypospolitej (1919-1939), Instytut Śląski, Opole 2004.

Nowodworski L., O ordynacji wyborczej do pierwszego Sejmu Polskiego: wyjaśnienie i wskazówki praktyczne, Drukarnia Jana Buriana, Warszawa 1918.

Ostateczny wynik wyborów na Pomorzu, „Dziennik Bydgoski” z 15 V 1920 r., nr 109.

Pajewski J., Odbudowa państwa polskiego 1914-1918, Państwowe Wydawnictwo Naukowe, Warszawa 1978.

Pietrzak J., O reprezentację bytego zaboru pruskiego w Sejmie Ustawodawczym w 1919 r., „Dzieje Najnowsze”, Zakład Narodowy im. Ossolińskich, Wydawnictwo Polskiej Akademii Nauk, Wrocław-Warszawa 1976, nr 4.

Pismo ustepujacego gabinetu do Naczelnika Państwa, „Kurier Polski” z 17 I 1919 r., nr 13.

Polityczny wiec kobiet polskich, „Nowa Gazeta” z 13 XI 1918 r., nr 47.

Program Moraczewskiego, „Czas” z 22 XII 1918 r., nr 511.

Przed wyborami, „Kurier Warszawski” z 9 I 1919 r., nr 9.

Przed wyborami, „Kurier Warszawski” z 21 I 1919 r., nr 21.

Rataj M., Pamiętniki (1918-1927), do druku przygotował J. Dębski, Ludowa Spółdzielnia Wydawnicza, Warszawa 1965.

Rok 1918 we wspomnieniach mężów stanu, polityków $i$ wojskowych, wybrał i opracował J. Borkowski, Państwowy Instytut Wydawniczy, Warszawa 1987.

Rostworowski M., Geneza państwa polskiego, Towarzystwo Biblioteki Słuchaczy Prawa Uniwersytetu Jagiellońskiego, Kraków 1921.

Rozmowa z ministrem spraw wewnętrznych, „Kurier Polski” z 11 XII 1918 r., nr 309.

Rzepecki T., Sejm Rzeczypospolitej Polskiej 1919 roku, Wielkopolska Księgarnia Narodowa, Poznań 1920.

Siemieński J., Rozbiór krytyczny ordynacji wyborczej do Sejmu Ustawodawczego, Księgarnia F. Hoesicka, Warszawa 1919.

Srebrakowski A., Sejm Wileński 1922 roku: idea i jej realizacja, „Acta Universitatis Wratislaviensis”, „Historia”, t. XCIX, Uniwersytet Wrocławski, Wrocław 1995. 
Śliwa M., Myśl polityczna Mieczysława Niedziałkowskiego (1893-1940), Państwowe Wydawnictwo Naukowe, Warszawa 1980.

Thugutt S., Autobiografia, przedmowa A. Więzikowa, T. Janczak, Ludowa Spółdzielnia Wydawnicza, Warszawa 1984.

Wiec kobiet polskich, „Bluszcz” z 30 XI 1918 r., nr 48.

Wybory do Sejmu, „Dziennik Poznański” z 5 VI 1919 r., nr 128.

Wybory do Sejmu na Pomorzu, „Dziennik Bydgoski” z 30 IV 1920 r., nr 98.

Wybory w Krakowie, „Naprzód” z 28 I 1919 r., nr 24.

Zawarcie kompromisu wyborczego, „Kurier Poznański” z 14 V 1919 r., nr 110.

Zwoliński W., Polski Sejm Konstytucyjny, czyli „,konstytuanta”, Skład Główny Redakcji „Zorzy", Warszawa 1918.

Zwołanie Sejmu, „Głos” z 30 XI 1918 r., nr 386. 